\title{
Plant-Produced Receptor-Binding Domain of SARS-CoV-2 Elicits Potent Neutralizing Responses in Mice and Non-human Primates
}

\author{
Konlavat Siriwattananon ${ }^{1,2}$, Suwimon Manopwisedjaroen ${ }^{3}$, Balamurugan Shanmugaraj, \\ Kaewta Rattanapisit ${ }^{4}$, Supaporn Phumiamorn ${ }^{5}$, Sompong Sapsutthipas ${ }^{5}$, \\ Sakalin Trisiriwanich, Eakachai Prompetchara ${ }^{6,7}$, Chutitorn Ketloy ${ }^{6,7}$, \\ Supranee Buranapraditkun ${ }^{6,8}$, Wassana Wijagkanalan ${ }^{9}$, Kittipan Tharakhet ${ }^{6}$, \\ Papatsara Kaewpang ${ }^{6}$, Kantinan Leetanasaksakul10, Taratorn Kemthong ${ }^{11}$, \\ Nutchanat Suttisan ${ }^{11}$, Suchinda Malaivijitnond ${ }^{11}$, Kiat Ruxrungtham ${ }^{6,8}$, \\ Arunee Thitithanyanont ${ }^{3}$ and Waranyoo Phoolcharoen ${ }^{1,2 *}$
}

OPEN ACCESS

Edited by:

Ryo Matsuda,

The University of Tokyo, Japan

Reviewed by:

Chiara Lico,

Italian National Agency for New Technologies, Energy and Sustainable Economic Development (ENEA), Italy

Silvana Petruccelli,

National University of La Plata,

Argentina

*Correspondence: Waranyoo Phoolcharoen

Waranyoo.P@chula.ac.th

Specialty section:

This article was submitted to

Plant Biotechnology,

a section of the journal

Frontiers in Plant Science

Received: 19 March 2021

Accepted: 15 April 2021

Published: 13 May 2021

Citation:

Siriwattananon $\mathrm{K}$,

Manopwisedjaroen $S$,

Shanmugaraj B, Rattanapisit K, Phumiamorn S, Sapsutthipas S,

Trisiriwanich S, Prompetchara E,

Ketloy C, Buranapraditkun S,

Wijagkanalan W, Tharakhet $K$,

Kaewpang P, Leetanasaksakul K,

Kemthong T, Suttisan N,

Malaivijitnond S, Ruxrungtham $K$,

Thitithanyanont $A$ and

Phoolcharoen W (2021)

Plant-Produced Receptor-Binding Domain of SARS-CoV-2 Elicits Potent

Neutralizing Responses in Mice

and Non-human Primates.

Front. Plant Sci. 12:682953.

doi: 10.3389/fpls.2021.682953

\begin{abstract}
${ }^{1}$ Research Unit for Plant-produced Pharmaceuticals, Chulalongkorn University, Bangkok, Thailand, ${ }^{2}$ Department of Pharmacognosy and Pharmaceutical Botany, Faculty of Pharmaceutical Sciences, Chulalongkorn University, Bangkok, Thailand, ${ }^{3}$ Department of Microbiology, Faculty of Science, Mahidol University, Bangkok, Thailand, ${ }^{4}$ BaiyaPhytopharm Co., Ltd., Bangkok, Thailand, ${ }^{5}$ Department of Medical Sciences, Ministry of Public Health, Institute of Biological Products, Nonthaburi, Thailand, ${ }^{6}$ Faculty of Medicine, Center of Excellence in Vaccine Research and Development (Chula Vaccine Research Center, Chula VRC), Chulalongkorn University, Bangkok, Thailand, ${ }^{7}$ Department of Laboratory Medicine, Faculty of Medicine, Chulalongkorn University, Bangkok, Thailand, ${ }^{8}$ Department of Medicine, Faculty of Medicine, Chulalongkorn University, Bangkok, Thailand, ${ }^{9}$ BioNet-Asia Co., Ltd., Bangkok, Thailand, ${ }^{10}$ National Center for Genetic Engineering and Biotechnology (BIOTEC), National Science and Technology Development Agency, Pathum Thani, Thailand, " National Primate Research Center of Thailand-Chulalongkorn University, Saraburi, Thailand
\end{abstract}

The emergence of coronavirus disease 2019 (COVID-19) caused by severe acute respiratory syndrome coronavirus 2 (SARS-CoV-2) has affected global public health and economy. Despite the substantial efforts, only few vaccines are currently approved and some are in the different stages of clinical trials. As the disease rapidly spreads, an affordable and effective vaccine is urgently needed. In this study, we investigated the immunogenicity of plant-produced receptor-binding domain (RBD) of SARS-CoV-2 in order to use as a subunit vaccine. In this regard, RBD of SARS-CoV-2 was fused with Fc fragment of human lgG1 and transiently expressed in Nicotiana benthamiana by agroinfiltration. The plant-produced RBD-Fc fusion protein was purified from the crude extract by using protein A affinity column chromatography. Two intramuscular administration of plant-produced RBD-Fc protein formulated with alum as an adjuvant have elicited high neutralization titers in immunized mice and cynomolgus monkeys. Further it has induced a mixed Th1/Th2 immune responses and vaccine-specific T-lymphocyte responses which was confirmed by interferon-gamma (IFN- $\gamma$ ) enzymelinked immunospot assay. Altogether, our results demonstrated that the plant-produced SARS-CoV-2 RBD has the potential to be used as an effective vaccine candidate against SARS-CoV-2. To our knowledge, this is the first report demonstrating the immunogenicity of plant-produced SARS-CoV-2 RBD protein in mice and nonhuman primates.

Keywords: COVID-19, SARS-CoV-2, receptor-binding domain, Nicotiana benthamiana, plant-produced recombinant protein, Fc fusion protein, subunit vaccine 


\section{INTRODUCTION}

In December 2019, the unknown pneumonia cases have been first reported in Wuhan, Hubei Province, China, which were initially reported to be caused by novel coronavirus (nCoV-2019) and later named as SARS-CoV-2. The disease condition associated with it is referred as Coronavirus Disease (COVID-19). The virus was closely related to the severe acute respiratory syndrome coronavirus (SARS-CoV) that cause massive outbreak in 20022003 (Amanat and Krammer, 2020; Li Q. et al., 2020; Malik et al., 2020; Quinlan et al., 2020; She et al., 2020; Singhal, 2020). In short time, the virus spreads rapidly to more than 200 countries (Malik et al., 2020; She et al., 2020). As of April 2021, more than 130 million confirmed cases with a toll of more than 2.9 million deaths were globally reported and the number of infected patients has still been exponentially increasing daily (World Health Organization, 2021). Furthermore, only few vaccines are currently approved. Thus, the development of affordable effective vaccine or therapeutics is highly essential to control and prevent the infection.

SARS-CoV-2 belongs to the family Coronaviridae in the genera of Betacoronavirus, which are known to infect mammals. Coronaviruses (CoVs) are enveloped and single-stranded positive sense RNA viruses (Banerjee et al., 2019; Amanat and Krammer, 2020; Li H. et al., 2020; Rabi et al., 2020; Yuki et al., 2020). The CoV genome consists of 6-11 open reading frames (ORFs) encoding for non-structural polyproteins and structural proteins. The SARS-CoVs have four major structural proteins such as spike (S) surface glycoprotein, membrane $(\mathrm{M})$ protein, envelope (E) protein, and nucleocapsid $(\mathrm{N})$ protein, which are essential for viral assembly and infection (Bosch et al., 2003; Masters, 2006; Banerjee et al., 2019; Li H. et al., 2020; Malla et al., 2020; Rabi et al., 2020; Yuki et al., 2020). S glycoprotein plays a major role in viral attachment to host cells during the viral infection and cleaved by the host proteases into S1 and S2 subunits. SARS-CoV2 infection starts with pre-fusion of receptor binding domain (RBD) located on the S1 subunit to host receptor, angiotensin converting enzyme 2 (ACE2 receptor) and followed by S2 subunit post-fusion, leading to viral RNA penetration into host cells ( $\mathrm{Li}$ et al., 2003; Li, 2016; Yuan et al., 2017; Walls et al., 2019; Rabi et al., 2020; Shanmugaraj et al., 2020c; Yuki et al., 2020; Zhou et al., 2020). In addition, RBD was known to elicit potent immune response and considered as prime target for eliciting of host neutralizing antibodies (Wang et al., 2018; Li H. et al., 2020; Smith et al., 2020). Furthermore, previous studies demonstrated that the sera isolated from animals immunized with inactivated SARS-CoV virus significantly neutralize the virus by inhibiting the binding of RBD with ACE2 receptor which proved that the antibodies targeting the RBD domain could prevent the virus infection (He et al., 2004, 2005a,b; Zhu et al., 2013; Li H. et al., 2020).

Currently, recombinant proteins are produced mainly by bacterial fermentation or mammalian cell cultures, which still have many limitations including high production costs, immunogenicity profile, and pathogen contamination (Kelley, 2009; Phoolcharoen et al., 2011; Gomes et al., 2016; Kodati et al., 2016; Fuenmayor et al., 2017; Kaur et al., 2018; Rattanapisit et al., 2019a). Plant expression system is considered as the cost-effective platform for the production of vaccine antigens, diagnostic reagents, valuable biopharmaceuticals such as therapeutic immunoglobulins, human enzymes, and human growth factors (Gleba et al., 2005; Miao et al., 2008; Phoolcharoen et al., 2011; Ahmad et al., 2019; Rattanapisit et al., 2019a,b, 2021). Plant expression system offers several advantages in terms of rapidity, flexibility, post-translational modification of recombinant proteins, safety due to lack of animal pathogen, toxin contamination and scalability compared to other available conventional systems (Vitale and Denecke, 1999; Ma et al., 2003; Phoolcharoen et al., 2011; Shahid and Daniell, 2016; Bellucci et al., 2017). Hence, plant platform can be considered as an alternative platform for economical production of commercially viable biopharmaceuticals and vaccines especially for developing countries during pandemic situation (Phoolcharoen et al., 2011; Shanmugaraj et al., 2020a).

In this study, we produced SARS-CoV-2 RBD-Fc fusion protein by fusing SARS-CoV-2 RBD to the Fc domain of human IgG1 at the C-terminus and cloned into geminiviral vector for expression in Nicotiana benthamiana plants. The plantproduced RBD-Fc showed specific binding with both human embryonic kidney 293 (HEK293) and Chinese hamster ovary (CHO) cells produced ACE2 protein. Further the plant-produced RBD-Fc was shown to be immunogenic and significantly boosted a humoral and cell-mediated immune response in both mice and cynomolgus macaques (Macaca fascicularis). Our results demonstrated that this plant-produced protein has the potential for use as a vaccine candidate against SARS-CoV-2.

\section{MATERIALS AND METHODS}

\section{Construction of SARS-CoV-2 RBD-Fc Plant Expression Vector}

The RBD of SARS-CoV-2 (SARS-CoV-2 RBD) (Genbank accession number: YP_009724390.1; F318-C617) was designed to anneal with $\mathrm{Fc}$ region of human immunoglobulin G1 (IgG1) (GenBank accession number: 4CDH_A) by peptide linker 3XGGGGs at the C-terminus (Figure 1). The nucleotide sequence of SARS-CoV-2 RBD was codon optimized and commercially synthesized (Genewiz, Suzhou, China) with XbaI and BamHI restriction sites for cloning with the Fc region, that contains BamHI and SacI restriction sites at the $5^{\prime}$ and $3^{\prime}$ ends, respectively. The SARS-CoV-2 RBD and human Fc region were ligated into a geminiviral vector (pBYR2eK2Md; pBYR2e) (Chen et al., 2011; Diamos and Mason, 2018) using XbaI and SacI restriction sites to construct the plant expression vector pBYR2e-SARS-CoV-2 RBD-Fc. The murine leader sequence (Shanmugaraj et al., 2020b) and ER retention signal peptide (SEKDEL) was included at $\mathrm{N}$-terminus and $\mathrm{C}$-terminus of the gene construct, respectively (Figure 1).

\section{Expression of SARS-CoV-2 RBD-Fc in Nicotiana benthamiana via., Agroinfiltration}

The plant expression vector pBYR2e-SARS-CoV-2 RBD-Fc was transformed into Agrobacterium tumefaciens strain GV3101 


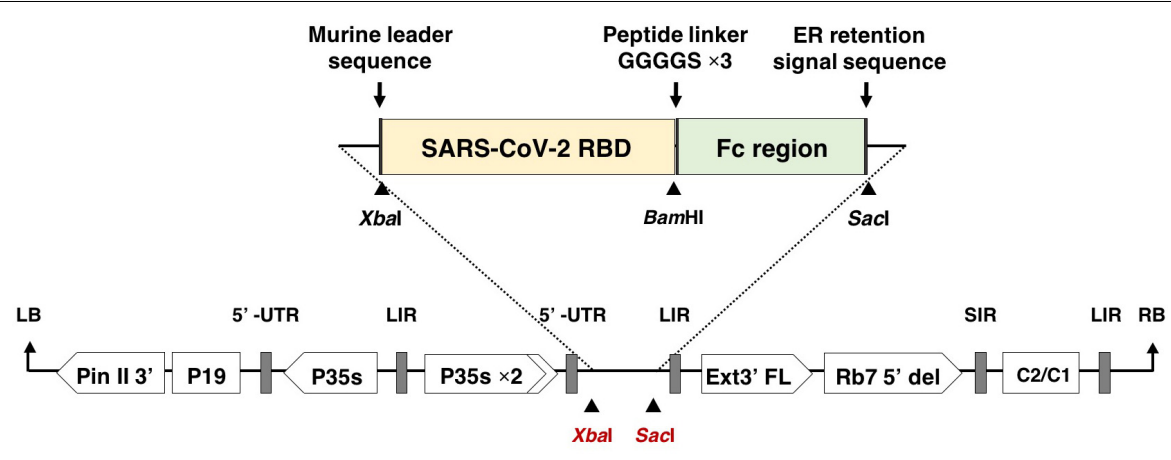

PBYR2e-SARS-CoV-2 RBD-Fc

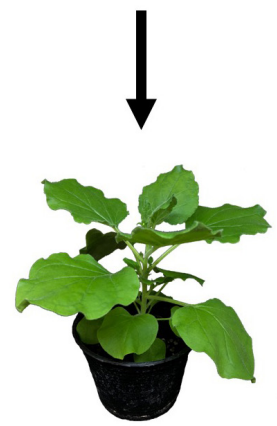

Transient expression in Nicotiana benthamiana

4 days post

agroinfiltration

SARS-CoV-2 RBD

Fc region

Plant-produced SARS-CoV-2

RBD-Fc fusion protein

FIGURE 1 | Diagrammatic representation showing the T-DNA of plant expression vector pBYR2e-SARS-CoV-2 RBD-Fc and the overview of transient expression in N. benthamiana plants. RB and LB, left and right borders of the T-DNA used in Agrobacterium DNA delivery into plant cells; Pin II 3', the terminator from potato proteinase inhibitor II gene; P19, the RNA silencing suppressor from Tomato Bushy Stunt Virus (TBSV); P35s, 35s promoter from Cauliflower Mosaic Virus (CaMV); P35s $\times$ 2, 35s promoter from CaMV with duplicated enhancer; Ext3' FL, 3' region of tobacco extension gene; Rb7 5' del, tobacco RB7 promoter; SIR, short intergenic region of Bean Yellow Dwarf Virus (BeYDV); LIR, long intergenic region of BeYDV; C2/C1, Rep/RepA gene from BeYDV encoding for replication initiation protein (Rep) and RepA.

cells by electroporation (MicroPulser, Bio-Rad, United States). The recombinant Agrobacterium clones were confirmed by polymerase chain reaction (PCR) using the RBD gene-specific primers. Agrobacterium containing pBYR2e-SARS-CoV-2 RBDFc was resuspended with 1xinfiltration buffer $(10 \mathrm{mM} 2-(\mathrm{N}-$ morpholino) etanesulfonic acid (MES), $10 \mathrm{mM} \mathrm{MgSO} 4$, at $\mathrm{pH}$ 5.5) to get final $\mathrm{OD}_{600}$ of 0.2 prior to agroinfiltration. The Agrobacterium suspension was injected into the adaxial side of 6-week-old $N$. benthamiana leaves. The infiltrated plants were maintained in an optimal 16-h light/8-h dark condition at $28^{\circ} \mathrm{C}$ and harvested after 4 days post infiltration (dpi).

\section{Purification of Plant-Produced SARS-CoV-2 RBD-Fc Fusion Protein}

The infiltrated leaves were harvested and extracted with $1 \times \mathrm{PBS}$ (phosphate-buffered saline: $137 \mathrm{mM} \mathrm{NaCl}, 2.68 \mathrm{mM} \mathrm{KCl}$, $10.1 \mathrm{mM} \mathrm{Na}_{2} \mathrm{HPO}_{4}, 1.76 \mathrm{mM} \mathrm{KH}_{2} \mathrm{PO}_{4} \mathrm{pH} 7.4$ ) and clarified by 
centrifugation at $26,000 \mathrm{~g}$ for $45 \mathrm{~min}$ at $4^{\circ} \mathrm{C}$. The supernatant was filtered by using $0.45 \mu \mathrm{m}$ S-Pak membrane (Merck, Massachusetts, United States). The clarified supernatant was purified by affinity column chromatography with protein-A beads (Expedeon, Cambridge, United Kingdom). The purified column was equilibrated and washed by 1xPBS pH 7.4 followed by elution with $0.1 \mathrm{M}$ glycine buffer $\mathrm{pH}$ 3. Subsequently, the $\mathrm{pH}$ of the eluted proteins was neutralized by using Tris- $\mathrm{HCl}$ $\mathrm{pH}$ 8.8. The purified SARS-CoV-2 RBD-Fc was concentrated by using Amicon ${ }^{\circledR}$ ultracentrifugal filter (Merck, Massachusetts, United States) and filtered through $0.22 \mu \mathrm{m}$ syringe filter (Merck, Massachusetts, United States). The purified plantproduced SARS-CoV-2 RBD-Fc fusion protein was analyzed by using sodium dodecyl sulfate-polyacrylamide gel electrophoresis (SDS-PAGE) and western blotting under reducing and nonreducing conditions. The SARS-CoV-2 RBD-Fc samples were subjected to $8 \%$ sodium dodecyl sulfate polyacrylamide gel electrophoresis and stained by Coomassie staining solution for protein visualization. For western blot analysis, the separated proteins were transferred to nitrocellulose membrane (Biorad, United States) and detected with a 1:5,000 sheep anti-human gamma chain-HRP conjugate antibody diluted in $1 x P B S$ (The Binding Site, United Kingdom). The yield of purified plantproduced RBD-Fc fusion protein was estimated by direct ELISA assay using human IgG (Abcam, United Kingdom) as protein standard. The samples were probed by using anti-human gamma chain-HRP fusion (The Binding Site, United Kingdom) at the dilution of $1: 1,000$ in 1xPBS. A 3,3,5,5'-Tetramethylbenzidine (TMB) solution (Promega, United States) was added into the plate as a colorimetric developer followed by the addition of $1 \mathrm{M}$ $\mathrm{H}_{2} \mathrm{SO}_{4}$. The absorbance at $450 \mathrm{~nm}$ was read using a 96-well plate reader (Molecular Devices, United States).

\section{Liquid Chromatography-Mass Spectrometry (LC-MS) of Plant-Produced SARS-CoV-2 RBD-Fc Fusion Protein}

The purified proteins were separated on SDS-PAGE. The targeted protein band was excised and sent to National Center for Genetic Engineering and Biotechnology, Pathum Thani, Thailand for LC-MS analysis. The protein was enzymatically digested with trypsin and injected into Hybrid quadrupole Q-Tof impact IITM (Bruker Daltonics Ltd., Hamburg, Germany) equipped with a Nano-captive spray ion source was coupled to a nanoLC system: Ultimate 3000 LC System (Thermo Fisher Scientific, United States). Equipment operation was controlled by Compass 1.9 software (Bruker Daltonics Ltd., Hamburg, Germany). The resulting MS/MS spectra were searched using the Mascot Sever (Matrix Science) against SwissProt database. For Mascot searches, the peptide mass tolerance was set at $0.6 \mathrm{Da}$ and the fragment mass tolerance was set at $1.2 \mathrm{Da}$.

\section{ACE2 Binding by ELISA}

The binding activity of plant-produced SARS-CoV-2 RBDFc fusion protein to ACE2 protein was demonstrated by ELISA. Briefly, 96-well ELISA plate was coated by $100 \mathrm{ng}$ of two different ACE2 protein derived either from HEK293-cells
(Abcam, United Kingdom) or CHO-cells (InvivoGen, California, United States). For blocking, 5\% skim milk in $1 \times$ PBS was added into the wells and incubated for $2 \mathrm{~h}$ at $37^{\circ} \mathrm{C}$. After blocking, the plate was washed three times with 1xPBST (1xPBS plus $0.05 \%$ Tween-20) and incubated with various concentrations of plantproduced SARS-CoV-2 RBD-Fc fusion protein in $1 x P B S$. The SARS-CoV-2 RBD proteins in the wells were detected by addition of 1: 100 dilution of plant-produced anti-SARS-CoV-2 (H4) mAb (Shanmugaraj et al., 2020b) and followed by a 1:1,000 dilution of anti-human Kappa chain-HRP fusion (SouthernBiotech, United States) in $1 \times$ PBS for $1 \mathrm{~h}$ at $37^{\circ} \mathrm{C}$. For colorimetric development, a TMB solution (Promega, United States) was added into the wells followed by addition of $1 \mathrm{M} \mathrm{H}_{2} \mathrm{SO}_{4}$ for terminating the enzymatic reaction. The absorbance at $450 \mathrm{~nm}$ was measured using a 96-well microplate reader (Molecular Devices, United States).

\section{Immunization of Mice and Non-human Primates}

Mice immunization protocols were approved by the Institutional Animal Care and Use Committee, Faculty of Medicine, Chulalongkorn University (Protocol review No. 012/2563). Seven-week-old female ICR mice ( $n=5$ per group) were intramuscularly (IM) immunized via., anterior tibialis with $10 \mu \mathrm{g}$ of plant-produced SARS-CoV-2 RBD-Fc fusion protein without adjuvant or formulated with $0.1 \mathrm{mg}$ alum (InvivoGen, California, United States) on days 0 and 21. Mice sera were collected prior to the first immunization (pre-bleed, day 0) and 14 days post-vaccination to assess the SARS-CoV-2-specific antibody response. The mice were sacrificed on day 35 (14 days after second booster) to collect the spleen for quantitative measurement of SARS-CoV-2 RBD-specific T-cell responses.

For non-human primate immunogenicity studies, all procedures were reviewed and approved by the National Primate Research Center of Thailand-Chulalongkorn University (NPRCT-CU) Animal Care and Use Committee (Protocol review No. 207512) and the facility has been AAALAC International Accredited (1752). Thirteen SPF juvenile cynomolgus macaques (Macaca fascicularis), aged between 2.5 and 3.5 years old, and body weight between 2.18 and $3.17 \mathrm{~kg}$, were assigned into three groups in which the control group $(n=3)$ was immunized by PBS adjuvanted with $0.5 \mathrm{mg}$ alum, and other two groups $(n=5$ per group) were administered with 25 and $50 \mu \mathrm{g}$ of plant-produced SARS-CoV-2 RBD-Fc fusion protein along with $0.5 \mathrm{mg}$ alum adjuvant, respectively. Monkeys were received two intramuscular injections on day 0 and 21. The blood samples were collected on day 0 (pre-immunization) and 14 days after each vaccination (days 14 and 35) to assess SARS-CoV-2 RBD specific IgG, neutralizing antibody and cell-mediated immune responses.

\section{Evaluation of SARS-CoV-2 RBD-Specific Total Antibody Responses by ELISA}

96-well plate was coated with $100 \mathrm{ng}$ of SARS-CoV-2 spike protein RBD derived from Sf9 insect cells (GenScript, United States) and incubated overnight at $4^{\circ} \mathrm{C}$. Then, the wells were blocked with 5\% skim milk powder in $1 \times$ PBS for 2 
$\mathrm{h}$ at $37^{\circ} \mathrm{C}$. Subsequently, the animal sera were twofold serially diluted with 1xPBS starting at 1:100 was loaded on the wells and incubated for $2 \mathrm{~h}$ at $37^{\circ} \mathrm{C}$. Goat anti-mouse IgG HRP conjugate antibody (Jackson ImmunoResearch, Pennsylvania, United States) and goat anti-monkey IgG HRP conjugation (Abcam, United Kingdom) diluted 1:2,000 in 1xPBS were added into the wells for detecting mouse and monkey antibodies, respectively, and the plate was incubated for $2 \mathrm{~h}$ at $37^{\circ} \mathrm{C}$. TMB substrate (Promega, United States) was added into the plates for colorimetric development. The enzymatic reactions were terminated by adding $1 \mathrm{M} \mathrm{H}_{2} \mathrm{SO}_{4}$. The absorbance was measured at $450 \mathrm{~nm}$ using a microplate reader (BMG Labtech, Germany). Between each step, the plates were washed by 1xPBST for three times. For mouse IgG1 and IgG2a analysis, the mice sera were twofold serially diluted with 1xPBS starting 1:100 in the same fashion and detected by 1:2,000 goat anti-mouse IgG1 (HRP) and goat anti-mouse IgG2a heavy chain (HRP) antibody (Abcam, United Kingdom), respectively, diluted in 1xPBS. The endpoint titer of IgG1 and IgG2a were also computed for monitoring Th2 and Th1 lymphocyte responses, respectively. The endpoint titers were determined as the highest dilution of immunized sera, which had $\mathrm{A}_{450}$ more than cut off calculated from $\mathrm{A}_{450}$ of pre-immunized sera in the dilution of 1:100 in 1xPBS (Frey et al., 1998). All experiments were performed in duplicates and 1xPBS was used as a control. The statistical analyses of immunological data were performed using GraphPad Prism software version 8.0. Statistical significance was calculated by two-way analysis of variance (ANOVA). All data in each group were compared by using Tukey's multiple comparisons test and the values of $p<0.05$ were considered as statistically significant.

\section{In vitro Microneutralization Assay}

Microneutralization assay was performed using Vero E6 cell line and live SARS-CoV-2 virus isolated from a COVID19 patient and conducted in a certified biosafety level 3 facility of Microbiology department, Faculty of Science, Mahidol University, Bangkok, Thailand. The cells were plated in 96-well plate at $1 \times 10^{4}$ cells/well in DMEM (Dulbecco's Modified Eagle's medium supplemented with $10 \%$ heat-inactivated FBS, $100 \mathrm{U} / \mathrm{mL}$ of penicillin and $0.1 \mathrm{mg} / \mathrm{mL}$ of streptomycin) and incubated for overnight. The immunized sera and positive convalescent serum from COVID-19 patient were heat-inactivated at $56^{\circ} \mathrm{C}$ for $30 \mathrm{~min}$. The immunized sera were twofold serially diluted in duplicates and incubated with 100 of $50 \%$ tissue culture infective dose $\left(\mathrm{TCID}_{50}\right)$ of the SARS-CoV-2 virus in DMEM at $37^{\circ} \mathrm{C}$ for $1 \mathrm{~h}$. Virus control at $100 \mathrm{TCID}_{50}$ and uninfected cell control wells were included in all plates. Subsequently, the mixture of diluted serum and virus was transferred to the cell monolayer and incubated at $37^{\circ} \mathrm{C}$ with $5 \% \mathrm{CO}_{2}$ for 2 days. After incubation, the cells were washed once with $1 \times P B S$ and then fixed and permeabilized with ice-cold 1:1 methanol/acetone fixative solution at $4^{\circ} \mathrm{C}$ for $20 \mathrm{~min}$. The cells were washed 3 times with 1xPBST and blocked with 2\% BSA at room temperature (RT) for $1 \mathrm{~h}$. After washing, the viral nucleocapsid was detected using 1:5,000 of SARS-CoV/SARSCoV-2 nucleocapsid (N) monoclonal antibody (SinoBiological, United States) and incubated at $37^{\circ} \mathrm{C}$ for $1 \mathrm{~h}$ followed by adding 1:2,000 of HRP-conjugated goat anti-rabbit polyclonal antibody (Dako, Denmark) diluted with 1xPBS and incubated at $37^{\circ} \mathrm{C}$ for $1 \mathrm{~h}$. The KPL Sureblue ${ }^{\mathrm{TM}} \mathrm{TMB}$ substrate (SeraCare, United States) was added for colorimetric development. Then the reaction was stopped by the addition of $1 \mathrm{~N} \mathrm{HCl}$. The absorbance at 450 and $620 \mathrm{~nm}$ was read by a Sunrise ${ }^{\mathrm{TM}}$ microplate reader (Tecan, Switzerland). The absorbance differences between 450 and $620 \mathrm{~nm}\left(\mathrm{~A}_{450}-\mathrm{A}_{620}\right)$ of diluted samples were compared with the $50 \%$ specific signal of the cut point, which was calculated by the following equation to determine the potent neutralization titers of the immunized sera.

$$
A_{\text {cutpoint }}=\left(\frac{A_{\text {virus control }}-A_{\text {cell control }}}{2}\right)+A_{\text {cell control }}
$$

Where $A_{\text {Virus control }}$ and $A_{\text {cell control }}$ are the average of $\mathrm{A}_{450}-\mathrm{A}_{620}$ of virus control wells and cell control wells, respectively. The neutralizing titers were defined as the reciprocal highest dilution providing the average of $\mathrm{A}_{450}-\mathrm{A}_{620}$ of the diluted serum well more than the cut point. The neutralizing antibody titers of each experimental group were compared by GraphPad Prism 8.0 using Mann-Whitney test. The significant differences were considered when $p<0.05$.

\section{Mouse IFN- $\gamma$ ELISPOT Assay}

For mouse splenocyte preparation, the spleen cells were aseptically plated in the petri-dish and dissociated into singlecell suspension using needle\#21 for 2-3 times. The separated splenocytes were cultured in R5 medium (RPMI1640 with $100 \mathrm{U} / \mathrm{mL}$ penicillin, $100 \mathrm{U} / \mathrm{mL}$ streptomycin, 5\% heatinactivated fetal bovine serum (FBS, Gibco, United States) and 2-mercaptoethanol) and centrifuged at $1,200 \mathrm{~g} 4^{\circ} \mathrm{C}$ for $5 \mathrm{~min}$. Subsequently, splenocytes were lysed with 1xACK lysis buffer, added $\mathrm{R} 5$ medium and collected the cell pellet by centrifugation at $1,200 \mathrm{~g} 4^{\circ} \mathrm{C}$ for $5 \mathrm{~min}$. Finally, splenocytes were counted and adjusted for using in ELISpot assay. The IFN- $\gamma$ secreting cells were quantified by using mouse IFN- $\gamma$ ELISpot assay kit (Mabtech, Stockholm, Sweden). Briefly, splenocytes were resuspended at $5 \times 10^{6}$ cells/mL in $\mathrm{R} 5$ medium. The 96-well plates (Millipore, Bedford, MA, United States) were coated with $500 \mathrm{ng}$ of anti-mouse IFN- $\gamma$ (AN18) monoclonal antibody (mAb) (Mabtech, Stockholm, Sweden) in $1 x P B S$ at $37^{\circ} \mathrm{C}$ with $5 \% \mathrm{CO}_{2}$ for $3 \mathrm{~h}$. Then, the plates were washed six times with 1xPBS and blocked with R10 medium at RT for $1 \mathrm{~h}$. A quantity of $5 \times$ $10^{5}$ splenocytes per well were activated by lyophilized SARSCoV-2 peptide pools (BioNet-Asia, Thailand, and Mimotopes, Australia) at a final concentration of $2 \mu \mathrm{g} / \mathrm{mL}$ at $37^{\circ} \mathrm{C}$ with $5 \%$ $\mathrm{CO}_{2}$ for $40 \mathrm{~h}$. R5 medium and concanavalin A (ConA) were used as negative and positive controls, respectively. After incubation, the plates were washed six times with 1xPBST followed by three times with 1xPBS. Then, the plates were incubated with antimouse IFN- $\gamma$-biotinylated mAb (Mabtech, Stockholm, Sweden) diluted in $1 \times$ PBS at RT for $3 \mathrm{~h}$. After washing, streptavidinalkaline phosphatase (ALP: Mabtech, Stockholm, Sweden) was added and incubated at RT for $1 \mathrm{~h}$. The substrate solution (5-bromo-4-chloro-3-indolyl-phosphate/nitro blue tetrazolium; $\mathrm{BCIP} / \mathrm{NBT}$ ) were added into the wells and incubated until distinct spots emerge. Reactions were stopped by washing 
extensively in tap water and rinsing the underside of membrane. Inspect and count spots were performed with an ELISpot reader (ImmunoSpot ${ }^{\circledR}$ Analyzer, United States). Results were expressed as spot-forming cells (SFCs) $/ 10^{6}$ splenocytes. The positive responses were defined as $>50 \mathrm{SFCs} / 10^{6}$ splenocytes over the background signal. The result analyses were conducted using Kruskal-Wallis test in GraphPad Prism 6.0. All $p$-values $<0.05$ were defined as significant.

\section{Non-human Primate IFN- $\gamma$ ELISpot Assay}

For peripheral blood mononuclear cells (PBMCs) preparation, the cells were isolated by density gradient separation using Isoprep (Robbins Scientific Corporation, CA). Briefly, after removal of plasma, EDTA-treated whole blood was diluted (1:1) with RPMI1640 medium containing $2 \mathrm{mM}$ L-Glutamine (Gibco, United States) and layered over Isoprep. Samples were then centrifuged at 1,200 $\mathrm{g}$ for $30 \mathrm{~min}$. The PBMC layer was harvested and washed twice with RPMI1640. Then, the cells were resuspended in R10 medium (RPMI1640 supplemented with 100 $\mathrm{U} / \mathrm{mL}$ of penicillin, $100 \mathrm{U} / \mathrm{mL}$ of streptomycin and $10 \%$ heatinactivated fetal bovine serum (FBS, Gibco, United States) for applying in ELISpot assay. The antigen-specific cells secreting monkey IFN- $\gamma$ were enumerated by using monkey IFN- $\gamma$ ELISpot assay kit (Mabtech, Stockholm, Sweden). Briefly, PBMCs were stimulated with SARS-CoV-2 spike peptides pools (BioNetAsia, Thailand, and Mimotopes, Australia) at $37^{\circ} \mathrm{C}$ with $5 \%$ $\mathrm{CO}_{2}$ for $40 \mathrm{~h}$. R5 medium and phytohemagglutinin (PHA) were served as negative and positive control, respectively. The secreted monkey IFN- $\gamma$ were detected by anti-monkey IFN$\gamma$-biotinylated mAb (Mabtech, Stockholm, Sweden) and followed by addition of ALP solution (Mabtech, Stockholm, Sweden). For spot development, BCIP/NBT-plus substrate solution was added into the wells and incubated until distinct spots emerge. The spots were inspected and counted by ELISpot reader (ImmunoSpot ${ }^{\circledR}$ Analyzer, Germany). Results were expressed as spot-forming cells (SFCs) $/ 10^{6}$ PBMCs following the subtraction of the negative control. The positive responses were defined $>100$ SFCs $/ 10^{6}$ PBMCs over the background. Statistical analyses were presented using GraphPad Prism 8.0. Comparison of frequencies of populations in each group was made using Friedman and MannWhitney tests. All $p$-values $<0.05$ were defined as significant.

\section{RESULTS}

\section{Transient Expression of SARS-CoV-2 RBD-Fc Fusion Protein in Nicotiana benthamiana}

The nucleotide sequence of RBD of SARS-CoV-2 was codonoptimized and fused with Fc region of human IgG1 at the $\mathrm{C}$ terminus of the RBD gene construct. The codon-optimized SARS-CoV-2 RBD-Fc fusion gene was cloned into the geminiviral plant expression vector pBYR2e. For expression of RBD-Fc fusion protein in plants, $N$. benthamiana plants were infiltrated with Agrobacterium containing pBYR2e-SARS-CoV-2 RBD-Fc (Figure 1). The leaves infiltrated with Agrobacterium containing
pBYR2e-SARS-CoV-2 RBD-Fc showed significant phenotypic necrosis compared to the leaves infiltrated by Agrobacterium without the plant expression vector (Figure 2A).

\section{Purification and Characterization of Plant-Produced RBD-Fc Fusion Protein}

Plant-produced SARS-CoV-2 RBD-Fc fusion protein was extracted and purified from crude extract by single-step protein A affinity chromatography. The purified SARS-CoV-2 RBD-Fc fusion protein was concentrated and filtered by using 0.22 $\mu \mathrm{m}$ syringe filter. The purity of the purified plant-produced SARS-CoV-2 RBD-Fc was analyzed by SDS-PAGE gel stained with Coomassie blue staining under reducing and non-reducing condition. The purity of SARS-CoV-2 RBD-Fc fusion protein was found to be higher than $90 \%$ based on the visual inspection of a Coomassie-stained SDS gel (Figure 2B). The SARS-CoV-2 RBD-Fc fusion protein was further analyzed by western blot probed with anti-human gamma chain-HRP conjugate antibody. The protein band corresponding to the molecular weight of $65 \mathrm{kDa}$ was observed in reducing condition (Figure 2C; lane 1). In addition, the plant-produced SARS-CoV-2 RBD-Fc fusion protein under non-reducing condition was observed at approximately $150 \mathrm{kDa}$ (Figure 2C; lane 2), which implies that the SARS-CoV-2 RBD-Fc fusion protein could be linked by disulfide bond into dimeric form. The expression level of plant-produced SARS-CoV-2 RBD-Fc was quantified by ELISA and found to be $25 \mu \mathrm{g} / \mathrm{g}$ fresh weight. The authenticity of purified plant-produced SARS-CoV-2 RBD-Fc fusion protein was further confirmed by using a high-resolution LC-TOF MS/MS analysis as shown in Supplementary Document.

\section{In vitro Binding Activity of Plant-Produced RBD-Fc Fusion Protein}

The binding of plant-produced SARS-CoV-2 RBD-Fc fusion protein was confirmed by ELISA by using commercial HEK293 and $\mathrm{CHO}$-produced ACE2 protein as the capture reagent. The various dilutions of purified plant-produced SARS-CoV2 RBD-Fc was incubated with commercial ACE2 proteins. For detection of SARS-CoV-2 RBD, anti-SARS-CoV-2 (H4) mAb (Shanmugaraj et al., 2020b) and anti-human kappa chain-HRP conjugate antibody were added into the wells. The results showed that plant-produced SARS-CoV-2 RBD-Fc fusion protein produced saturable binding to both commercial ACE2 proteins with substantially high affinity in comparison to PBS control (Figure 3), which confirms the authenticity of plant-produced SARS-CoV-2 RBD-Fc.

\section{Immunogenicity in Mice}

Mice immunogenicity was assessed in 7-week-old female Mlac:ICR mice by immunizing intramuscularly on days 0 and 21 with $10 \mu \mathrm{g}$ of plant-produced SARS-CoV-2 RBD-Fc fusion protein with or without alum adjuvant. Mice sera were collected on days 0, 14, and 35 (Figure 4A). SARS-CoV-2 RBD-specific antibodies were evaluated by ELISA using commercial SARSCoV-2 RBD-His protein produced from Sf9 cells as a capture antigen. The SARS-CoV-2 RBD-specific immune responses were 


\section{A}

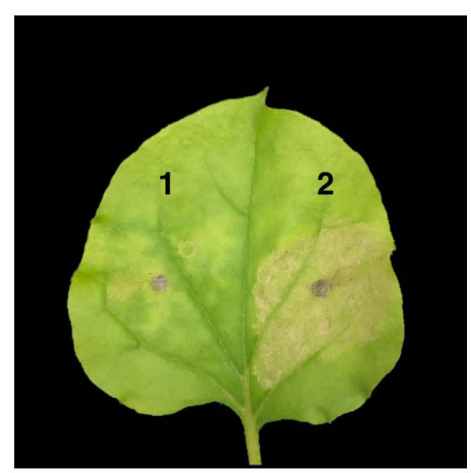

B

C
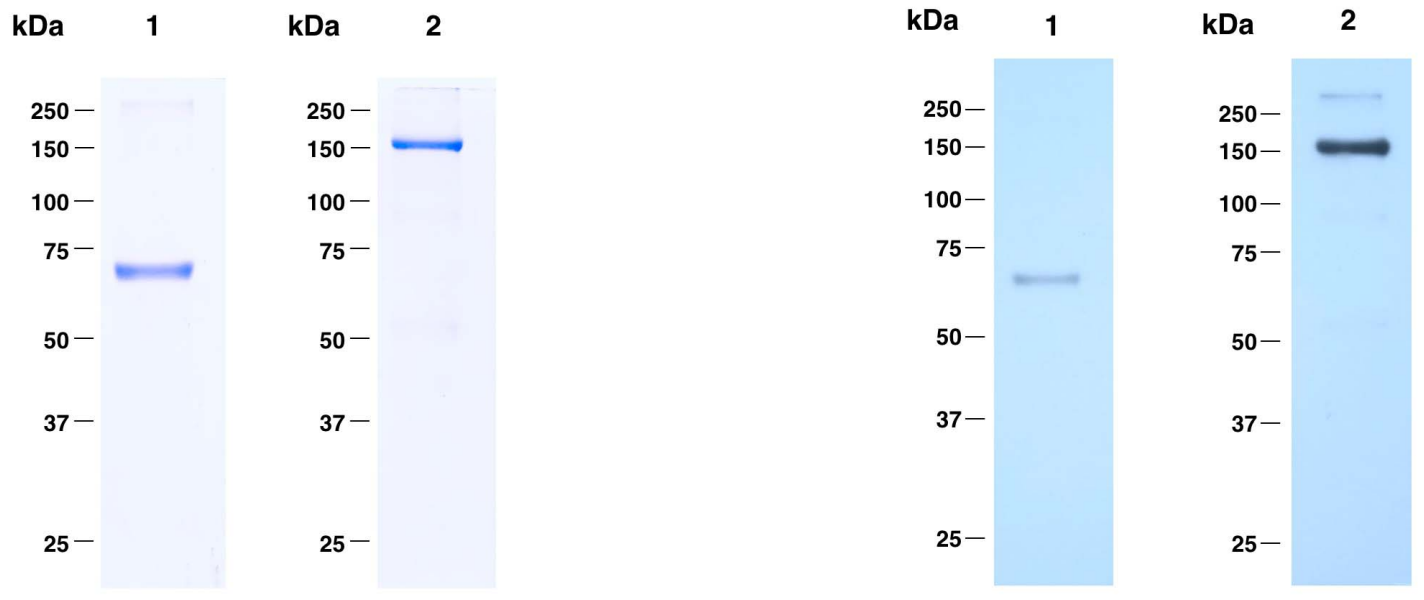

FIGURE 2 | Expression profiles of plant-produced SARS-CoV-2 RBD-Fc fusion protein. Phenotype of leaf infiltrated with Agrobacterium control (1) and Agrobacterium containing pBYR2e-SARS-CoV-2 RBD-Fc (2) after 4 dpi (A). SDS-PAGE analysis of plant-produced SARS-CoV-2 RBD-Fc fusion protein stained with Coomassie staining (B) and western blot of plant-produced SARS-CoV-2 RBD-Fc fusion protein probed with anti-human gamma-HRP conjugate antibody (C). Lane 1 and 2, purified plant-produced SARS-CoV-2 RBD-Fc fusion protein under reducing and non-reducing condition, respectively.

observed after first immunization of plant-produced SARS-CoV2 RBD-Fc alone, whilst a slightly increased specific-mouse total IgG response was observed in SARS-CoV-2 RBD-Fc immunized with alum. All mice immunized with plant-produced RBD-Fc elicited significantly higher antibody titer after second booster compared with the control group (Figure 4B). Plant-produced SARS-CoV-2 RBD-Fc was found to be immunogenic, while the addition of alum adjuvant could significantly improve its immunogenicity. In addition, we appraised the levels of SARSCoV-2 RBD-specific IgG1 and IgG2a subclasses, which are indicators of Th2 and Th1 lymphocyte responses in mice, respectively. The results demonstrated that plant-produced SARS-CoV-2 RBD-Fc induced both SARS-CoV-2 RBD-specific IgG1 (Figure 4C) and IgG2a (Figure 4D) with the IgG1 bias. The in vitro neutralizing ability of the immunized sera was evaluated. The SARS-CoV-2 RBD-Fc without adjuvant induced neutralizing antibody against SARS-CoV-2 after the second dose at a dilution of 1:1,280 (Figure 4E). Interestingly, mice sera immunized by
SARS-CoV-2 RBD-Fc adjuvanted with alum displayed maximum SARS-CoV-2 neutralization with a dilution more than 1:10,240 (Figure 4E). IFN- $\gamma$ levels of splenocytes isolated from mice was tested by IFN- $\gamma$ ELISpot assay. The results showed that plantproduced RBD-Fc elicited IFN- $\gamma$ secretion which was statistically significant compared with mock control group (Figure 4F).

\section{Immunogenicity in Non-human Primates}

Cynomolgus macaques (Macaca fascicularis) were intramuscularly immunized with 25 and $50 \mu \mathrm{g}$ of plant-produced SARS-CoV-2 RBD-Fc with the presence of alum on day 0 and 21. Monkey sera were collected on day 0, 14, and 35 (Figure 5A). Plant-produced SARS-CoV-2 RBD-Fc protein adjuvanted with alum was capable of inducing dose-independent SARS-CoV-2 RBD-specific IgG antibodies in monkeys after first and second immunization with the dilution 1:800, and 1:51,200, respectively (Figure 5B). Specifically, the microneutralization assay was performed by using Vero E6 cell line to evaluate the level of 


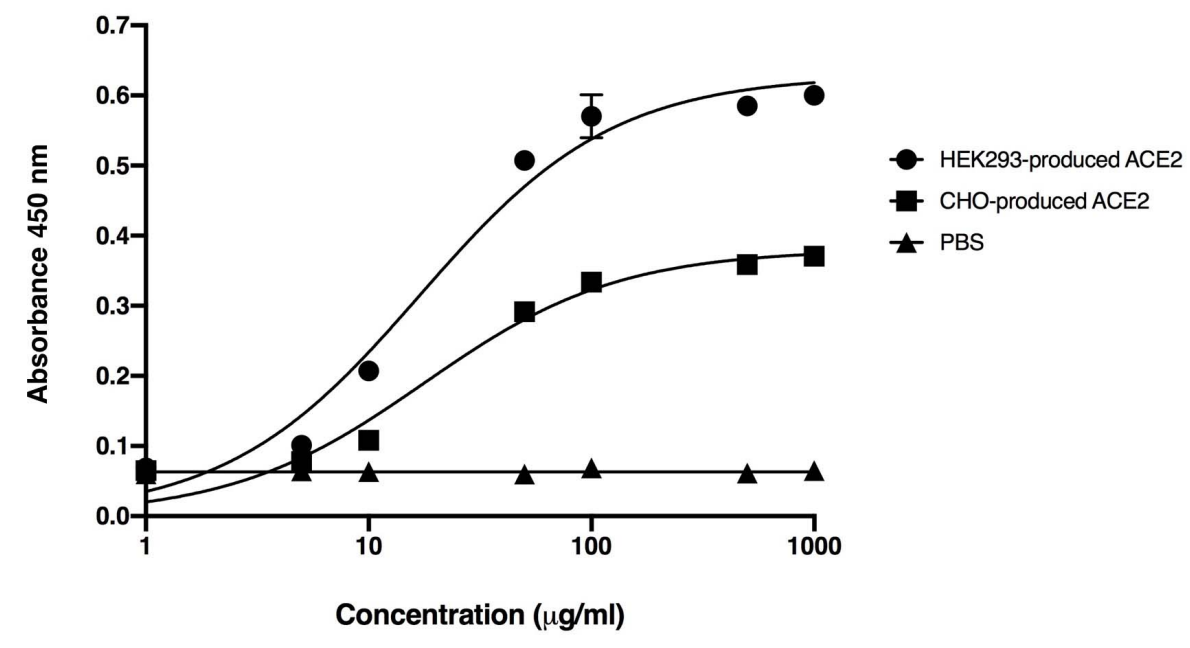

FIGURE 3 | Binding activity of the plant-produced SARS-CoV-2 RBD-Fc with the commercial angiotensin-converting enzyme 2 (ACE2 proteins) derived from HEK293 and CHO cells analyzed by ELISA. PBS was used as negative control. Data are presented as mean \pm standard deviation (SD) of triplicates in each sample dilution.

neutralizing antibodies against live SARS-CoV-2. Sera collected 14 days after the first immunization (day 14) showed neutralizing activity against the SARS-CoV-2 and increased at day 35 (14 days after the second immunization) with the neutralization titer approximately 5,120 (Figure 5C). In addition, cell-mediated immune responses in cynomolgus monkeys were monitored by IFN- $\gamma$ ELISpot assay by using peripheral blood mononuclear cells isolated from immunized sera on day 35 . The specific IFN- $\gamma$ expression was detected in monkeys immunized with two doses of plant-produced SARS-CoV-2 RBD-Fc, and a significant difference from the control group was detected compared to immunized monkeys (Figure 5D).

\section{DISCUSSION}

The recent emergence of coronavirus diseases (COVID-19) in China is responsible for the current global pandemic and public health crisis (Li Q. et al., 2020; Malik et al., 2020; Singhal, 2020; Yuki et al., 2020). Few vaccines are currently approved for human use. Hence, it is highly essential to develop safe, effective vaccines and therapeutics against this infection to prevent its spread. Recently, several groups have predicted and assessed the immunogenicity potential of SARS-CoV-2 related proteins and showed that SARS-CoV-2 S protein is the suitable candidate for recombinant vaccine development as it can elicit potent immune response and is the major target of neutralizing antibodies. The receptor-binding domain (RBD) of SARS-CoV-2 plays a key role in viral attachment and entry into the host cells by interaction with the ACE2 receptor in the host cells (Li et al., 2003; Lei et al., 2020; Quinlan et al., 2020; Rabi et al., 2020; Shanmugaraj et al., 2020c; Sun et al., 2020; Xie et al., 2020; Yuki et al., 2020). Particularly, RBD domain has multiple conformational epitopes, which can induce host immune responses and highly potent neutralizing antibodies (He et al., 2005a,b; Zhu et al., 2013; Wang et al., 2018; Smith et al., 2020). Hence, RBD domain in the S protein is considered as a potential target and could serve as a potent immunogen for developing the possible SARS-CoV2 vaccines.

Since 1980s, plants have been utilized for the development of highly valuable biopharmaceuticals either for human or veterinary applications. Plant-based expression system offers several key advantages over conventional systems in terms of production speed, cost, and safety (Basaran and RodríguezCerezo, 2008; Paul and Ma, 2011; Krenek et al., 2015; Yao et al., 2015; Burnett and Burnett, 2019; Shanmugaraj et al., 2020a; Daniell et al., 2021). Remarkably, plant-based expression system can produce large amounts of recombinant antigens in a relatively short time period within few weeks after making the gene construct (D’Aoust et al., 2008, 2010; Rybicki, 2009; Vézina et al., 2009; Pillet et al., 2016; Rattanapisit et al., 2020; Ward et al., 2020). The concept of plant-produced biopharmaceuticals and vaccines has been assessed and well explored by number of research groups worldwide. Several plant-produced therapeutics (Kizhner et al., 2015; Ma et al., 2015; Mor, 2015; Prevail Ii Writing Group et al., 2016) and vaccines (Yuki et al., 2013; Hendin et al., 2017; Donini and Marusic, 2019) are currently in pipeline for clinical trials and approval, Notably plant-produced Glucocerebrosidase enzyme (Elelyso ${ }^{\mathrm{TM}}$ ) for the treatment of type I Gaucher's disease has been approved by US Food and Drug Administration (Fox, 2012) and tobacco-derived seasonal flu VLP vaccine from Medicago Inc., is currently in final stages of clinical trial (Ward et al., 2021). Hence, plant-based expression could be an alternative option for rapid production of emergency vaccines or therapeutic antibodies (Iyappan et al., 2018; DiegoMartin et al., 2020; Rattanapisit et al., 2020; Shanmugaraj and Phoolcharoen, 2021; Siriwattananon et al., 2021).

The geographical distribution of virus is increasing rapidly and global concern on this pandemic demands an affordable and scalable protein production platform that can produce 
A

\section{Immunization groups}

PBS + $0.1 \mathrm{mg}$ Alum (Control) $(n=5)$

$10 \mu \mathrm{g}$ RBD-Fc $(\mathrm{n}=5)$

$10 \mu \mathrm{g}$ RBD-Fc $+0.1 \mathrm{mg}$ Alum $(\mathrm{n}=5)$
Day 0

First immunization

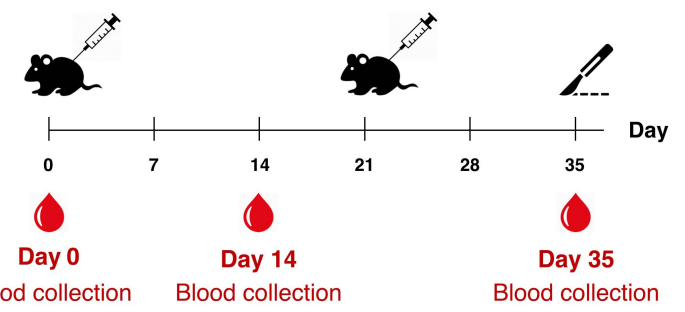

B

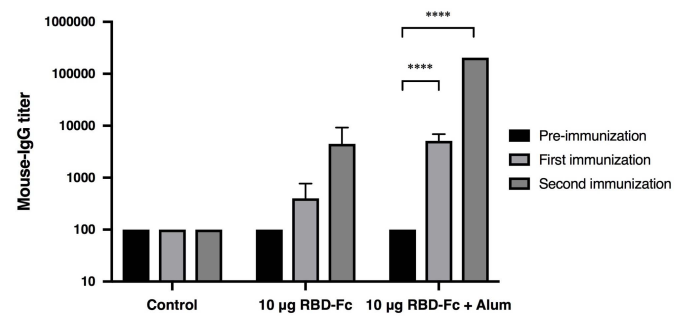

D

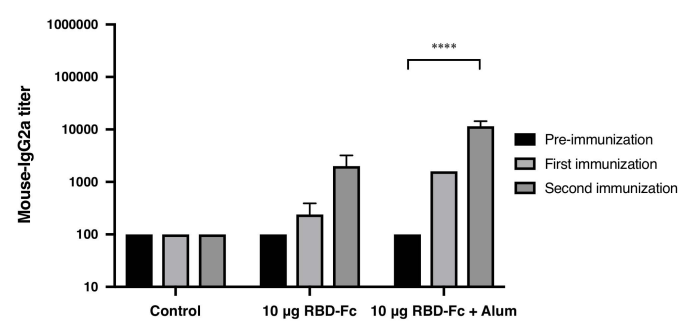

C

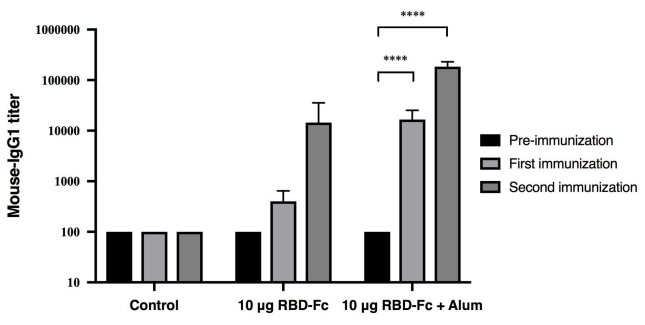

E

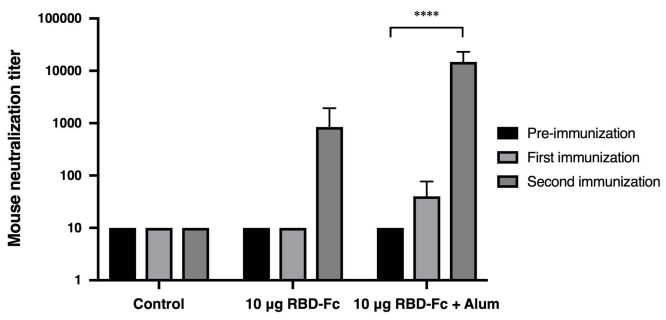

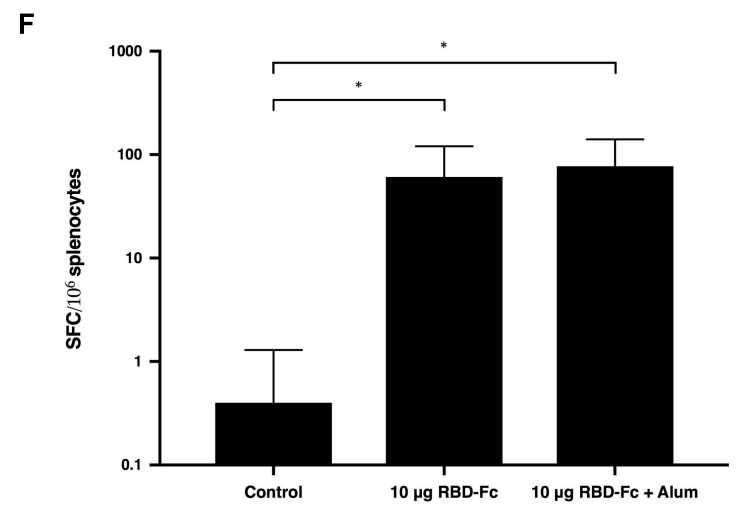

FIGURE 4 | Immunogenic studies in mice. Schematic representation of immunization protocol and sample collection. Groups of mice (five mice per each group) were intramuscularly immunized with $10 \mu \mathrm{g}$ of SARS-CoV-2 RBD-FC fusion protein alone or with alum adjuvant, followed by booster dose at 21 days after first immunization. Mice sera were collected on day 0 (pre-bleed) and day 14 post-immunization (A). Titers of SARS-CoV-2 RBD-specific total lgG (B), IgG1 (C), and IgG2a (D) in the immunized sera collected on day 0,14 , and 35 were analyzed by indirect ELISA using Sf9-produced SARS-CoV-2 RBD-His as the capture antigen. Potent neutralizing antibody titers in mice sera were tested by in vitro microneutralization assay using Vero E6 cell line and live SARS-CoV-2 (E). The functional profiles of SARS-CoV-2 RBD-specific T-cell responses expressing in mouse splenocytes immunized with plant-produced SARS-CoV-2 RBD-Fc adjuvanted with alum were determined by mouse ELISpot assay (F). Data presented as mean \pm SD of the endpoint titers in each mice vaccination group $(n=5)$. ${ }^{*} p<0.05$; ${ }^{* *} p<0.01 ;{ }^{* * *} p<0.001 ;{ }^{* * *} p<0.0001$. 
A

$\begin{array}{cc}\text { Day } 0 & \text { Day 21 } \\ \text { immunization } & \text { Second immunization }\end{array}$

\begin{abstract}
Immunization groups
PBS $+0.5 \mathrm{mg}$ Alum (Control) $(\mathrm{n}=3)$

$25 \mu \mathrm{g}$ RBD-Fc $+0.5 \mathrm{mg}$ Alum $(\mathrm{n}=5)$

$50 \mu \mathrm{g}$ RBD-Fc + $0.5 \mathrm{mg}$ Alum $(\mathrm{n}=5)$
\end{abstract}

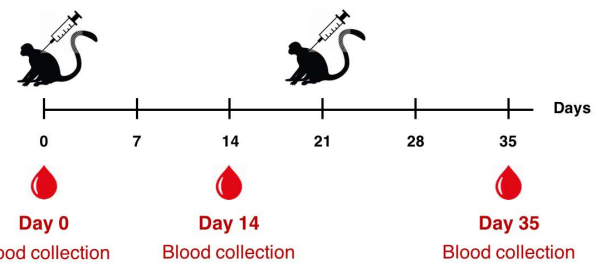

B

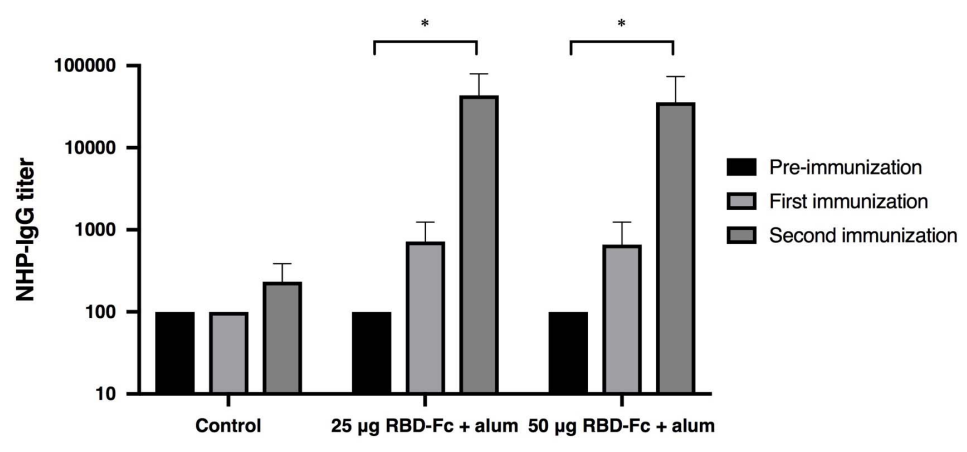

C

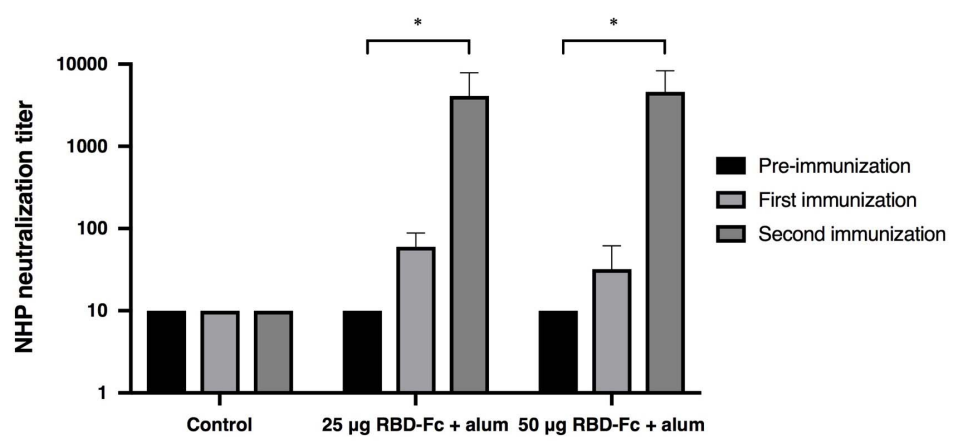

D

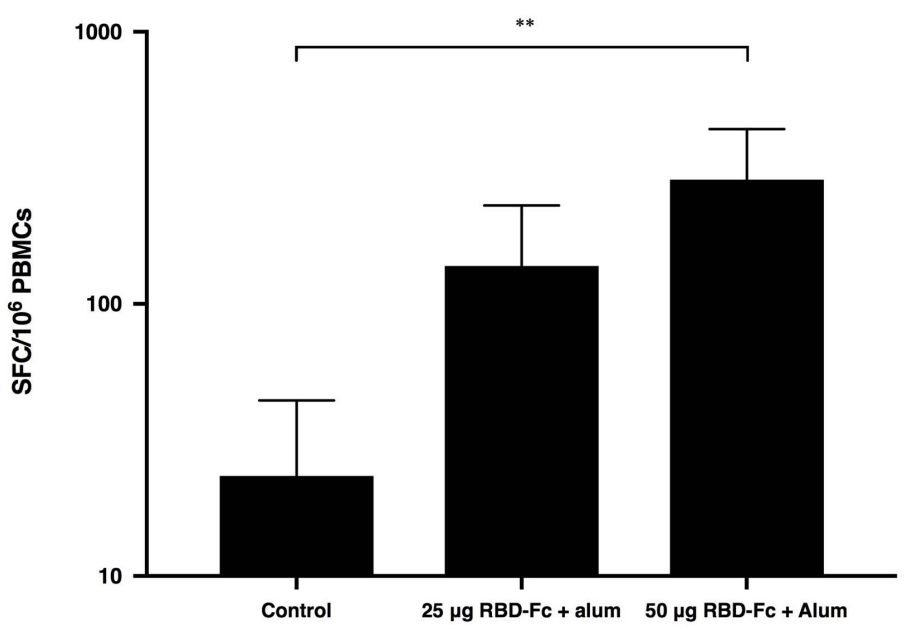

FIGURE 5 | Immunogenic studies in non-human primates (Macaca fascicularis). Experimental design of immunogenicity studies in non-human primates. Thirteen juvenile-adult non-human primates were separated into 3 groups; Control group was immunized with PBS adjuvanted by alum $(n=3)$ and two experimental groups were immunized with 25 and $50 \mu \mathrm{g}$ SARS-CoV-2 RBD-Fc along with alum adjuvant ( $n=5$ per group). All non-human primates were intramuscularly injected either with PBS or plant-produced RBD-FC for 3 weeks interval (on day 0 and 21). The sera were collected on day 0 and 14 after each boost (A). Serum specific lgG response in non-human primates were determined by ELISA (B). Virus neutralizing titer of RBD immunized non-human primate sera against live SARS-CoV-2 were evaluated (C). The functional profiles of SARS-CoV-2 RBD-specific T-cell responses expressing in non-human primate peripheral blood mononuclear cells immunized with plant-produced RBD-Fc adjuvanted with alum on day 14 after second immunization (D). ${ }^{*} p<0.05 ;{ }^{* *} p<0.01 ;{ }^{* * *} p<0.001 ;{ }^{* * * *} p<0.0001$. 
recombinant proteins relatively in short time with much reduced cost. Hence in this study, we have demonstrated the rapid production of SARS-CoV-2 RBD-Fc fusion protein in $N$. benthamiana plants that could be used as a potential vaccine candidate for prevention of SARS-CoV-2 infection.

Significant efforts have been made by the scientific community across the world to develop the effective vaccine against SARS$\mathrm{CoV}$-2. Plant-derived vaccine candidates for other coronaviruses such as SARS and porcine epidemic diarrhea virus are shown to elicit potent immunogenic response in animal studies (Kang et al., 2005; Pogrebnyak et al., 2005). Earlier studies showed that full length $S$ protein-based vaccine could cause liver damage or enhance virus infection. RBD-based vaccines formulated with alum was shown to elicit high level of protective immunity in animal experiments (He et al., 2006; Du et al., 2007; Jiang et al., 2012; Chen et al., 2017, 2020a,b). Hence based on the available data on the immunogenicity of SARS-CoV-2 proteins, we have chosen RBD for plant expression.

The presence of $\mathrm{Fc}$ domain in fusion protein offers favorable characteristics such as improving the expression and secretion of the recombinant proteins, improving protein solubility and stability (Huang, 2009; Czajkowsky et al., 2012; Yang et al., 2018). Moreover, Fc domain increases the serum half-life and prolongs therapeutic protein activities due to $\mathrm{pH}$-dependent binding to the neonatal $\mathrm{Fc}$ receptor ( $\mathrm{FCRn}$ ) leading to prevention of protein degradation in endosomes as well as reduces renal clearance rate due to larger molecular weight of protein (Jazayeri and Carroll, 2008; Suzuki et al., 2010; Carter, 2011; Rath et al., 2015; Rosales-Mendoza et al., 2017; Yang et al., 2018). Fc region have been used as a fusion protein partner for several recombinant proteins such as receptors, ligands, enzymes, and soluble cytokines for therapeutic applications (Strohl and Knight, 2009; Li and Ravetch, 2011; Czajkowsky et al., 2012; Rattanapisit et al., 2019c; Liu et al., 2020). In addition to the mentioned advantages, Fc region is used as a tagged protein for facilitating the effective purification of recombinant protein by protein $\mathrm{A}$ chromatography that can provide high purity of SARS-CoV-2 RBD-Fc which can be visualized on the Coomassie-stained SDSPAGE compared to crude extract sample as shown in previous studies (Rattanapisit et al., 2019c; Siriwattananon et al., 2021). Hence, we engineered SARS-CoV-2 RBD by fusing with Fc region of human IgG1 in order to use it as a subunit vaccine against SARS-CoV-2.

The SARS-CoV-2 RBD-Fc fusion protein was transiently expressed as a soluble protein in plants. The results showed that the expression of SARS-CoV-2 RBD-Fc was achieved rapidly within 4 days post infiltration with necrosis signal was observed on the infiltrated leaves (Figure 2A). The recombinant protein was purified from the plant crude extracts by affinity column chromatography and used for further studies.

The plant-produced SARS-CoV-2 RBD-Fc apparently showed effective binding activity with commercial ACE2 proteins produced from HEK293 and CHO cells (Figure 3). This data indicated that the SARS-CoV-2 RBD protein folded correctly in plants and produced authentic antigen. The immunogenicity of plant-produced SARS-CoV-2 RBD-Fc was tested in mice and cynomolgus monkeys using alum as an adjuvant. Alum stimulates the innate immunity, particularly presenting the antigen to major histocompatibility complex (MHC) class II, CD40 and CD86 or inducing the Th2 responses to mediate $\mathrm{B}$-cell differentiation and elicit the antigen specific-IgG1 isotype (Marrack et al., 2009; Exley et al., 2010; Zhang et al., 2016). Furthermore, alum is having good safety profile and has been used as an adjuvant in several currently available licensed vaccines to enhance the immune response of the antigen (HogenEsch et al., 2018).

Mice administered with two doses of plant-derived SARSCoV-2 RBD-Fc protein formulated with alum as adjuvant developed the neutralizing immune response (Figure $4 \mathrm{E}$ ). The results confirmed the immunogenicity of plant-produced recombinant SARS-CoV-2 RBD protein. Mice immunized with RBD with alum showed the higher titer of neutralizing antibodies compared with the mice immunized with SARSCoV-2 RBD alone. The analysis of the mouse specificIgG subtypes suggested that plant-produced SARS-CoV-2 RBD induced a mixed Th1/Th2-specific immune responses. Further the efficacy of plant-produced SARS-CoV-2 RBDFc fusion protein was investigated in cynomolgus monkeys by administering the SARS-CoV-2 RBD-Fc with alum as adjuvant. The results confirmed that the plant-produced SARS-CoV-2 RBD-Fc could induce neutralizing antibodies in monkeys (Figure 5C). To accomplish the capability of plantproduced SARS-CoV-2 RBD-Fc in induction of cell-mediated immune responses, mouse splenocytes and monkey peripheral blood mononuclear cells were collected 14 days after second immunization (Figures 4F, 5D). The IFN- $\gamma$-expressing $\mathrm{T}$ cells were analyzed by ELISPOT assay. Plant-produced SARSCoV-2 RBD-Fc without alum induced SARS-CoV-2-specific $\mathrm{T}$-cell responses, as evidenced by significant IFN- $\gamma$ expression compared with the control (Figure 4F). Addition of alum adjuvant did not significantly increase the number of IFN- $\gamma$ in the animals. These results suggested that plant-produced SARSCoV-2 RBD-Fc itself could induce T-cell responses.

These results clearly showed that the plant-expressed SARSCoV-2 RBD-Fc fusion protein maintains their authentic structure and retains its antigenicity. Our results are consistent with those of previous studies which showed that the vaccine antigens expressed in $N$. benthamiana elicited potent immune responses in animal experiments (Zheng et al., 2009; He et al., 2014). In consistent with earlier reports on the immunogenicity of RBD of SARS-CoV, our study showed that neutralizing antibodies induced by plant produced RBD of SARS-CoV-2 suppress SARSCoV-2 infection in vitro (Bisht et al., 2005; Kapadia et al., 2005; Du et al., 2010). Our data showed the potential of plant-produced subunit vaccine candidate as the effective SARS-CoV-2 vaccine.

\section{CONCLUSION}

In conclusion, our study demonstrated that it was feasible to produce SARS-CoV-2 RBD protein in $N$. benthamiana plants by transient expression system. Further plant-produced recombinant protein was shown to be immunogenic in mice and non-human primates. The vaccine elicited both humoral 
and cell mediated immune responses suggesting the potential of plant- produced RBD as the effective vaccine against SARS-CoV2. To our knowledge, this is the first report demonstrating the immunogenicity of plant-produced SARS-CoV-2 RBD protein in mice and non-human primates. Collectively this proof of concept study demonstrated that the plant-produced SARS-CoV2 proteins could possibly be further developed as candidate vaccines for early stage clinical development.

\section{DATA AVAILABILITY STATEMENT}

The original contributions presented in the study are included in the article/Supplementary Material, further inquiries can be directed to the corresponding author/s.

\section{ETHICS STATEMENT}

The animal study was reviewed and approved by the Institutional Animal Care and Use Committee, Faculty of Medicine and the National Primate Research Center of Thailand-Chulalongkorn University (NPRCT-CU) Animal Care and Use Committee, Chulalongkorn University, Bangkok, Thailand.

\section{AUTHOR CONTRIBUTIONS}

KiR, AT, and WP designed all experiments. KS, BS, and KaR performed protein expression, protein purification, ELISA, and protein preparation for animal experiments. KS, SMan, SP,

\section{REFERENCES}

Ahmad, A. R., Kaewpungsup, P., Khorattanakulchai, N., Rattanapisit, K., Pavasant, P., and Phoolcharoen, W. (2019). Recombinant human dentin matrix protein 1 (hDMP1) expressed in Nicotiana benthamiana potentially induces osteogenic differentiation. Plants 8:566. doi: 10.3390/plants8120 566

Amanat, F., and Krammer, F. (2020). SARS-CoV-2 vaccines: status report. Immunity 52, 583-589. doi: 10.1016/j.immuni.2020.03.007

Banerjee, A., Kulcsar, K., Misra, V., Frieman, M., and Mossman, K. (2019). Bats and Coronaviruses. Viruses 11:41. doi: 10.3390/v11010041

Basaran, P., and Rodríguez-Cerezo, E. (2008). Plant molecular farming: opportunities and challenges. Crit. Rev. Biotechnol. 28, 153-172. doi: 10.1080/ 07388550802046624

Bellucci, M., Marchis, F. D., and Pompa, A. (2017). The endoplasmic reticulum is a hub to sort proteins toward unconventional traffic pathways and endosymbiotic organelles. J. Exp. Bot. 69, 7-20. doi: 10.1093/jxb/erx286

Bisht, H., Roberts, A., Vogel, L., Subbarao, K., and Moss, B. (2005). Neutralizing antibody and protective immunity to SARS coronavirus infection of mice induced by a soluble recombinant polypeptide containing an N-terminal segment of the spike glycoprotein. Virology 334, 160-165. doi: 10.1016/j.virol. 2005.01.042

Bosch, B. J., Zee, R. V. D., Haan, C. A. M. D., and Rottier, P. J. M. (2003). The coronavirus spike protein is a class I virus fusion protein: structural and functional characterization of the fusion core complex. J. Virol. 77, 8801-8811. doi: 10.1128/JVI.77.16.8801-8811.2003

Burnett, M. J. B., and Burnett, A. C. (2019). Therapeutic recombinant protein production in plants: Challenges and opportunities. Plants People Planet 2, 121-132. doi: 10.1002/ppp3.10073
SS, ST, EP, CK, SB, WW, KT, and PK performed vaccination and immunogenic studies in mice. KS, SMan, SP, SS, ST, $\mathrm{SB}, \mathrm{WW}, \mathrm{TK}, \mathrm{NS}$, and SMal performed vaccination and immunogenic studies in non-human primates. KL performed LC-MS analysis. All authors analyzed the data and contributed to manuscript preparation.

\section{FUNDING}

This research was funded by Baiya Phytopharm Co., Ltd. and TSRI Fund to SM and WP (CU_FRB640001_01_33_2). The authors declare that Baiya Phytopharm Co., Ltd. was not involved in the study design, collection, analysis, interpretation of data, the writing of this article or the decision to submit it for publication.

\section{ACKNOWLEDGMENTS}

We would like to thank the Department of Disease Control, Ministry of Public Health, Thailand for providing clinical specimens for the viral isolate and sera from a COVID19 survivor. We would like to thank the 100th anniversary Chulalongkorn University (KS) for doctoral scholarship.

\section{SUPPLEMENTARY MATERIAL}

The Supplementary Material for this article can be found online at: https://www.frontiersin.org/articles/10.3389/fpls.2021. 682953/full\#supplementary-material

Carter, P. J. (2011). Introduction to current and future protein therapeutics: a protein engineering perspective. Exp. Cell Res. 317, 1261-1269. doi: 10.1016/ j.yexcr.2011.02.013

Chen, Q., He, J., Phoolcharoen, W., and Mason, H. S. (2011). Geminiviral vectors based on bean yellow dwarf virus for production of vaccine antigens and monoclonal antibodies in plants. Hum. Vaccin. 7, 331-338. doi: 10.4161/hv.7. 3.14262

Chen, W.-H., Chag, S. M., Poongavanam, M. V., Biter, A. B., Ewere, E. A., Rezende, W., et al. (2017). Optimization of the production process and characterization of the yeast-expressed SARS-CoV recombinant receptorbinding domain (RBD219-N1), a SARS vaccine candidate. J. Pharm. Sci. 106, 1961-1970. doi: 10.1016/j.xphs.2017.04.037

Chen, W.-H., Strych, U., Hotez, P. J., and Bottazzi, M. E. (2020a). The SARS-CoV2 vaccine pipeline: an overview. Curr. Trop. Med. Rep. 3, 1-4. doi: 10.1007/ s40475-020-00201-6

Chen, W.-H., Tao, X., Agrawal, A., Algaissi, A., Peng, B.-H., Pollet, J., et al. (2020b). Yeast-expressed SARS-CoV recombinant receptor-binding domain (RBD219-N1) formulated with alum induces protective immunity and reduces immune enhancement. bioRxiv [preprint] doi: 10.1101/2020.05.15. 098079

Czajkowsky, D. M., Hu, J., Shao, Z., and Pleass, R. J. (2012). Fc-fusion proteins: new developments and future perspectives. EMBO Mol. Med. 4, 1015-1028. doi: 10.1002/emmm.201201379

D’Aoust, M.-A., Couture, M. M.-J., Charland, N., Trépanier, S., Landry, N., Ors, F., et al. (2010). The production of hemagglutinin-based virus-like particles in plants: a rapid, efficient and safe response to pandemic influenza. Plant Biotechnol. J. 8, 607-619. doi: 10.1111/j.1467-7652.2009.00496.x

D’Aoust, M.-A., Lavoie, P.-O., Couture, M. M.-J., Trépanier, S., Guay, J.-M., Dargis, M., et al. (2008). Influenza virus-like particles produced by transient expression 
in Nicotiana benthamiana induce a protective immune response against a lethal viral challenge in mice. Plant Biotechnol. J. 6, 930-940. doi: 10.1111/j.14677652.2008.00384.x

Daniell, H., Jin, S., Zhu, X. G., Matthew, A., Gitzendanner, Soltis, D. E., et al. (2021). Green giant-a tiny chloroplast genome with mighty power to produce high-value proteins: history and phylogeny. Plant Biotechnol. J. 19, 430-447. doi: $10.1111 /$ pbi.13556

Diamos, A. G., and Mason, H. S. (2018). High-level expression and enrichment of norovirus virus-like particles in T plants using modified geminiviral vectors. Protein Expr. Purif. 151, 86-92. doi: 10.1016/j.pep.2018.06.011

Diego-Martin, B., González, B., Vazquez-Vilar, M., Selma, S., Mateos-Fernández, R., Gianoglio, S., et al. (2020). Pilot production of SARS-CoV-2 related proteins in plants: a proof of concept for rapid repurposing of indoor farms into biomanufacturing facilities. Front. Plant Sci. 11:612781. doi: 10.3389/fpls.2020. 612781

Donini, M., and Marusic, C. (2019). Current state-of-the-art in plant-based antibody production systems. Biotechnol. Lett. 41, 335-346. doi: 10.1007/ s10529-019-02651-z

Du, L., Zhao, G., Chan, C. C., Li, L., He, Y., Zhou, Y., et al. (2010). A 219-mer CHOexpressing receptor-binding domain of SARS-CoV S protein induces potent immune responses and protective immunity. Viral. Immunol. 23, 211-219. doi: 10.1089/vim.2009.0090

Du, L., Zhao, G., He, Y., Guo, Y., Zheng, B.-J., Jiang, S., et al. (2007). Receptorbinding domain of SARS-CoV spike protein induces long-term protective immunity in an animal model. Vaccine 25, 2832-2838. doi: 10.1016/j.vaccine. 2006.10.031

Exley, C., Siesjö, P., and Eriksson, H. (2010). The immunobiology of aluminium adjuvants: how do they really work? Trends Immunol. 31, 103-109. doi: 10.1016/ j.it.2009.12.009

Fox, J. L. (2012). First plant-made biologic approved. Nat. Biotechnol. 30:472. doi: $10.1038 /$ nbt0612-472

Frey, A., Canzio, J. D., and Zurakowski, D. (1998). A statistically defined endpoint titer determination method for immunoassays. J. Immunol. Methods 221, 3541. doi: 10.1016/s0022-1759(98)00170-7

Fuenmayor, J., Gòdia, F., and Cervera, L. (2017). Production of virus-like particles for vaccines. N. Biotechnol. 39, 174-180. doi: 10.1016/j.nbt.2017.07.010

Gleba, Y., Klimyuk, V., and Marillonnet, S. (2005). Magnifection-a new platform for expressing recombinant vaccines in plants. Vaccine 23, 2042-2048. doi: 10.1016/j.vaccine.2005.01.006

Gomes, A. R., Munivenkatappa, S., Belamaranahally, B., Veeregowda, M., and Balamurugan, V. (2016). An overview of heterologous expression host systems for the production of recombinant proteins. Adv. Anim. Vet. Sci. 4, 346-356. doi: 10.14737/journal.aavs/2016/4.7.346.356

Prevail Ii Writing Group, Multi-National Prevail Ii Study Team, Davey, R. T. Jr., Dodd, L., Proschan, M. A., Neaton, J., et al. (2016). A randomized, controlled trial of ZMapp for ebola virus infection. N. EngI. J. Med. 375, 1448-1456. doi: 10.1056/nejmoa1604330

He, J., Peng, L., Lai, H., Hurtado, J., Stahnke, J., and Chen, Q. (2014). A plantproduced antigen elicits potent immune responses against West Nile virus in mice. Biomed. Res. Int. 2014:952865. doi: 10.1155/2014/952865

He, Y., Li, J., Li, W., Lustigman, S., Farzan, M., and Jiang, S. (2006). Crossneutralization of human and palm civet severe acute respiratory syndrome coronaviruses by antibodies targeting the receptor-binding domain of spike protein. J. Immunol. 176, 6085-6092. doi: 10.4049/jimmunol.176.10.6085

He, Y., Lu, H., Siddiqui, P., Zhou, Y., and Jiang, S. (2005a). Receptor-binding domain of severe acute respiratory syndrome coronavirus spike protein contains multiple conformation-dependent epitopes that induce highly potent neutralizing antibodies. J. Immunol. 174, 4908-4915. doi: 10.4049/jimmunol. 174.8.4908

He, Y., Zhou, Y., Siddiqui, P., and Jianga, S. (2004). Inactivated SARS-CoV vaccine elicits high titers of spike protein-specific antibodies that block receptor binding and virus entry. Biochem. Biophys. Res. Commun. 325, 445-454. doi: 10.1016/j. bbrc.2004.10.052

He, Y., Zhu, Q., Liu, S., Zhou, Y., Yang, B., Li, J., et al. (2005b). Identification of a critical neutralization determinant of severe acute respiratory syndrome (SARS)-associated coronavirus: importance for designing SARS vaccines. Virology 334, 74-82. doi: 10.1016/j.virol.2005.01.034
Hendin, H. E., Pillet, S., Lara, A. N., Wu, C.-Y., Charland, N., Landry, N., et al. (2017). Plant-made virus-like particle vaccines bearing the hemagglutinin of either seasonal (H1) or avian (H5) influenza have distinct patterns of interaction with human immune cells in vitro. Vaccine 35, 2592-2599. doi: 10.1016/j. vaccine.2017.03.058

HogenEsch, H., O’Hagan, D. T., and Fox, C. B. (2018). Optimizing the utilization of aluminum adjuvants in vaccines: you might just get what you want. NPJ Vaccines 3:51. doi: 10.1038/s41541-018-0089-x

Huang, C. (2009). Receptor-Fc fusion therapeutics, traps, and MIMETIBODY technology. Curr. Opin. Biotechnol. 20, 692-699. doi: 10.1016/j.copbio.2009.10. 010

Iyappan, G., Shanmugaraj, B. M., Inchakalody, V., Ma, J. K. C., and Ramalingam, S. (2018). Potential of plant biologics to tackle the epidemic like situations case studies involving viral and bacterial candidates. Int. J. Infect. Dis. 73:363. doi: 10.1016/j.ijid.2018.04.4236

Jazayeri, J. A., and Carroll, G. J. (2008). Fc-based cytokines: prospects for engineering superior therapeutics. Biodrugs 22, 11-26. doi: 10.2165/00063030200822010-00002

Jiang, S., Bottazzi, M. E., Du, L., Lustigman, S., Tseng, C.-T. K., Curti, E., et al. (2012). Roadmap to developing a recombinant coronavirus $S$ protein receptorbinding domain vaccine for severe acute respiratory syndrome. Exp. Rev. Vacc. 11, 1405-1413. doi: 10.1586/erv.12.126

Kang, T.-J., Kim, Y.-S., Jang, Y.-S., and Yang, M.-S. (2005). Expression of the synthetic neutralizing epitope gene of porcine epidemic diarrhea virus in tobacco plants without nicotine. Vaccine 23, 2294-2297. doi: 10.1016/j.vaccine. 2005.01.027

Kapadia, S. U., Rose, J. K., Lamirande, E., Vogel, L., Subbarao, K., and Robertsc, A. (2005). Long-term protection from SARS coronavirus infection conferred by a single immunization with an attenuated VSV-based vaccine. Virology 340, 174-182. doi: 10.1016/j.virol.2005.06.016

Kaur, J., Kumar, A., and Kaur, J. (2018). Strategies for optimization of heterologous protein expression in E. coli: roadblocks and reinforcements. Int. J. Biol. Macromol. 106, 803-822. doi: 10.1016/j.ijbiomac.2017.08.080

Kelley, B. (2009). Industrialization of mAb production technology: the bioprocessing industry at a crossroads. MABS 1, 443-452. doi: $10.4161 /$ mabs.1.5.9448

Kizhner, T., Azulay, Y., Hainrichson, M., Tekoah, Y., Arvatz, G., Shulman, A., et al. (2015). Characterization of a chemically modified plant cell culture expressed human a-Galactosidase-A enzyme for treatment of Fabry disease. Mol. Genet Metab. 114, 259-267. doi: 10.1016/j.ymgme.2014.08.002

Kodati, B., Dorbha, S., and Kunaparaju, R. K. (2016). Heterologus protein expression in different host systems. J. Chem. Pharm. Res. 8, 1068-1074.

Krenek, P., Samajova, O., Luptovciak, I., Doskocilova, A., Komis, G., and Samaj, J. (2015). Transient plant transformation mediated by Agrobacterium tumefaciens: principles, methods and applications. Biotechnol. Adv. 33, 10241042. doi: 10.1016/j.biotechadv.2015.03.012

Lei, C., Qian, K., Li, T., Zhang, S., Fu, W., Ding, M., et al. (2020). Neutralization of SARS-CoV-2 spike pseudotyped virus by recombinant ACE2-Ig. Nat. Commun. 11:2070. doi: 10.1038/s41467-020-16048-4

Li, F. (2016). Structure, function, and evolution of coronavirus spike proteins. Annu. Rev. Virol. 3, 237-261. doi: 10.1146/annurev-virology-110615-042301

Li, F., and Ravetch, J. V. (2011). Inhibitory Fc $\gamma$ receptor engagement drives adjuvant and anti-tumor activities of agonistic CD40 antibodies. Science 333, 1030-1034. doi: 10.1126/science. 1206954

Li, H., Liu, S.-M., Yu, X.-H., Tang, S.-L., and Tang, C.-K. (2020). Coronavirus disease 2019 (COVID-19): current status and future perspectives. Int. J. Antimicrob. Agents 55:105951. doi: 10.1016/j.ijantimicag.2020.105951

Li, Q., Guan, X., Wu, P., Wang, X., Zhou, L., Tong, Y., et al. (2020). Early transmission dynamics in Wuhan, China, of novel coronavirus-infected pneumonia. N. Engl. J. Med. 382, 1199-1207. doi: 10.1056/NEJMoa2001316

Li, W., Moore, M. J., Vasilieva, N., Sui, J., Wong, S. K., Berne, M. A., et al. (2003). Angiotensin-converting enzyme 2 is a functional receptor for the SARS coronavirus. Nature 426, 450-454. doi: 10.1038/nature02145

Liu, Z., Xu, W., Xia, S., Gu, C., Wang, X., Wang, Q., et al. (2020). RBD-Fc-based COVID-19 vaccine candidate induces highly potent SARS-CoV-2 neutralizing antibody response. Signal. Transduct. Target. Ther. 5:282. doi: 10.4172/21671079.1000255 
Ma, J. K.-C., Drake, P. M. W., and Christou, P. (2003). The production of recombinant pharmaceutical proteins in plants. Nat. Rev. Genet. 4, 794-805. doi: $10.1038 / \operatorname{nrg} 1177$

Ma, J. K.-C., Drossard, J., Lewis, D., Altmann, F., Boyle, J., Christou, P., et al. (2015). Regulatory approval and a first-in-human phase I clinical trial of a monoclonal antibody produced in transgenic tobacco plants. Plant Biotechnol. J. 13, 1106-1120. doi: 10.1111/pbi.12416

Malik, Y. S., Sircar, S., Bhat, S., Sharun, K., Dhama, K., Dadar, M., et al. (2020). Emerging novel coronavirus (2019-nCoV)—current scenario, evolutionary perspective based on genome analysis and recent developments. Vet. Q. 40, 68-76. doi: 10.1080/01652176.2020.1727993

Malla, A., Shanmugaraj, B., and Ramalingam, S. (2020). Severe Acute Respiratory Syndrome Coronavirus-2 (SARS-CoV-2): An Emerging Zoonotic Respiratory Pathogen in Humans. J. Pure. Appl. Microbiol. 14, 931-936. doi: 10.22207/ JPAM.14.SPL1.30

Marrack, P., McKee, A. S., and Munks, M. W. (2009). Towards an understanding of the adjuvant action of aluminium. Nat. Rev. Immunol. 9, 287-293. doi: $10.1038 /$ nri2510

Miao, Y., Ding, Y., Sun, Q.-Y., Xu, Z.-F., and Jiang, L. (2008). Plant bioreactors for pharmaceuticals. Biotechnol. Genet. Eng. Rev. 25, 363-380. doi: 10.5661/bger25-363

Mor, T. S. (2015). Molecular pharming's foot in the FDA's door: protalix's trailblazing story. Biotechnol. Lett. 37, 2147-2150. doi: 10.1007/s10529-0151908-z

Paul, M., and Ma, J. K. C. (2011). Plant-made pharmaceuticals: leading products and production platforms. Biotechnol. Appl. Biochem. 58, 58-67. doi: 10.1002/ bab.6

Phoolcharoen, W., Bhoo, S. H., Lai, H., Ma, J., Arntzen, C. J., Chen, Q., et al. (2011). Expression of an immunogenic Ebola immune complex in Nicotiana benthamiana. Plant Biotechnol. J. 9, 807-816. doi: 10.1111/j.1467-7652.2011. 00593.x

Pillet, S., Aubin, É, Trépanier, S., Bussière, D., Dargis, M., Poulin, J.-F., et al. (2016). A plant- derived quadrivalent virus like particle influenza vaccine induces crossreactive antibody and $\mathrm{T}$ cell response in healthy adults. Clin. Immunol. 168, 72-87. doi: 10.1016/j.clim.2016.03.008

Pogrebnyak, N., Golovkin, M., Andrianov, V., Spitsin, S., Smirnov, Y., Egolf, R., et al. (2005). Severe acute respiratory syndrome (SARS) S protein production in plants: development of recombinant vaccine. Proc. Natl. Acad. Sci. U. S. A. 102, 9062-9067. doi: 10.1073/pnas.0503760102

Quinlan, B. D., Mou, H., Zhang, L., Guo, Y., He, W., Ojha, A., et al. (2020). The SARS-CoV-2 receptor-binding domain elicits a potent neutralizing response without antibody-dependent enhancement. bioRxiv [preprint] doi: 10.1101/ 2020.04.10.036418

Rabi, F. A., Zoubi, M. S. A., Kasasbeh, G. A., Salameh, D. M., and Al-Nasser, A. D. (2020). SARS-CoV-2 and coronavirus disease 2019: what we know so far. Pathogens 9:231. doi: 10.3390/pathogens9030231

Rath, T., Baker, K., Dumont, J. A., Peters, R. T., Jiang, H., Qiao, S.-W., et al. (2015). Fc-fusion proteins and FcRn: structural insights for longer-lasting and more effective therapeutics. Crit. Rev. Biotechnol. 35, 235-254. doi: 10.3109/07388551. 2013.834293

Rattanapisit, K., Chao, Z., Siriwattananon, K., Huang, Z., and Phoolcharoen, W. (2019a). Plant-produced anti-enterovirus 71 (EV71) monoclonal antibody efficiently protects mice against EV71 infection. Plants 8:12. doi: 10.3390/ plants8120560

Rattanapisit, K., Phakham, T., Buranapraditkun, S., Siriwattananon, K., Boonkrai, C., Pisitkun, T., et al. (2019b). Structural and in vitro functional analyses of novel plant-produced anti-Human PD1 antibody. Sci. Rep. 9:15205. doi: 10. 1038/s41598-019-51656-1

Rattanapisit, K., Shanmugaraj, B., Manopwisedjaroen, S., Purwono, P. B., Siriwattananon, K., Khorattanakulchai, N., et al. (2020). Rapid and scalable production of functional anti-coronavirus monoclonal antibody CR3022 in plants. Sci. Rep. 10:17698. doi: 10.21203/rs.3.rs-27160/v1

Rattanapisit, K., Srifa, S., Kaewpungsup, P., Pavasant, P., and Phoolcharoen, W. (2019c). Plant-produced recombinant Osteopontin-Fc fusion protein enhanced osteogenesis. Biotechnol. Rep. 21:e00312. doi: 10.1016/j.btre.2019.e00312

Rattanapisit, K., Yusakul, G., Shanmugaraj, B., Kittirotruji, K., Suwatsrisakul, P., Prompetchara, E., et al. (2021). Plant-produced recombinant SARS-CoV2 receptor-binding domain; an economical, scalable biomaterial source for
COVID-19 diagnosis. Biomater. Transl. 2, 43-49. doi: 10.3877/cma.j.issn.2096112X.2021.01.006

Rosales-Mendoza, S., Nieto-Gómez, R., and Angulo, C. (2017). A perspective on the development of plant-made vaccines in the fight against Ebola virus. Front. Immunol. 8:252. doi: 10.3389/fimmu.2017.00252

Rybicki, E. P. (2009). Third international conference on plant-based vaccines and antibodies. Expert. Rev. Vacc. 8, 1151-1155. doi: 10.1586/erv.09.85

Masters, S. P. (2006). The molecular biology of coronaviruses. Adv. Virus Res. 66, 193-292. doi: 10.1016/s0065-3527(06)66005-3

Shahid, N., and Daniell, H. (2016). Plant-based oral vaccines against zoonotic and non-zoonotic diseases. Plant Biotechnol. J. 14, 2079-2099. doi: 10.1111/pbi. 12604

Shanmugaraj, B., Bulaon, C. J. I., and Phoolcharoen, W. (2020a). Plant molecular farming: A viable platform for recombinant biopharmaceutical production. Plants 9:842. doi: 10.3390/plants9070842

Shanmugaraj, B., and Phoolcharoen, W. (2021). Addressing demand for recombinant biopharmaceuticals in the COVID-19 era. Asian Pac. J. Trop. Med. 14, 49-51.

Shanmugaraj, B., Rattanapisit, K., Manopwisedjaroen, S., Thitithanyanont, A., and Phoolcharoen, W. (2020b). Monoclonal antibodies B38 and H4 produced in Nicotiana benthamiana neutralize SARS-CoV-2 in vitro. Front. Plant Sci. 11:589995. doi: 10.3389/fpls.2020.589995

Shanmugaraj, B., Siriwattananon, K., Wangkanont, K., and Phoolcharoen, W. (2020c). Perspectives on monoclonal antibody therapy as potential therapeutic intervention for Coronavirus disease-19 (COVID-19). Asian Pac. J. Allergy Immunol. 38, 10-18. doi: 10.12932/ap-200220-0773

She, J., Jiang, J., Ye, L., Hu, L., Bai, C., and Song, Y. (2020). 2019 novel coronavirus of pneumonia in Wuhan, China: emerging attack and management strategies. Clin. Transl. Med. 9:19. doi: 10.1186/s40169-020-00271-z

Singhal, T. (2020). A review of coronavirus disease-2019 (COVID-19). Indian J. Pediatr. 87, 281-286. doi: 10.1007/s12098-020-03263-6

Siriwattananon, K., Manopwisedjaroen, S., Kanjanasirirat, P., Purwono, P. B., Rattanapisit, K., Shanmugaraj, B., et al. (2021). Development of plant-produced recombinant ACE2-Fc fusion protein as a potential therapeutic agent against SARS-CoV-2. Front. Plant Sci. 11:604663. doi: 10.3389/fpls.2020.604663

Smith, T. R. F., Patel, A., Ramos, S., Elwood, D., Zhu, X., Yan, J., et al. (2020). Immunogenicity of a DNA vaccine candidate for COVID-19. Nat. Commun. 11:2601. doi: 10.1038/s41467-020-16505-0

Strohl, W. R., and Knight, D. M. (2009). Discovery and development of biopharmaceuticals: current issues. Curr. Opin. Biotechnol. 20, 668-672. doi: 10.1016/j.copbio.2009.10.012

Sun, X., Wang, T., Cai, D., Hu, Z., Chen, J. A., Liao, H., et al. (2020). Cytokine storm intervention in the early stages of COVID-19 pneumonia. Cytokine Growth Factor Rev. 53, 38-42. doi: 10.1016/j.cytogfr.2020.04.002

Suzuki, T., Ishii-Watabe, A., Tada, M., Kobayashi, T., Kanayasu-Toyoda, T., Kawanishi, T., et al. (2010). Importance of neonatal FcR in regulating the serum half-life of therapeutic proteins containing the Fc domain of human IgG1: a comparative study of the affinity of monoclonal antibodies and Fc-fusion proteins to human neonatal FcR. J. Immunol. 184, 1968-1976. doi: 10.4049/ jimmunol.0903296

Vézina, L.-P., Faye, L., Lerouge, P., D’Aoust, M.-A., Marquet-Blouin, E., Burel, C., et al. (2009). Transient co-expression for fast and high-yield production of antibodies with human-like N-glycans in plants. Plant Biotechnol. J. 7, 442-455. doi: 10.1111/j.1467-7652.2009.00414.x

Vitale, A., and Denecke, J. R. (1999). The endoplasmic reticulum-gateway of the secretory pathway. Plant Cell 11, 615-628. doi: 10.1105/tpc.11.4.615

Walls, A. C., Xiong, X., Park, Y.-J., Tortorici, M. A., Snijder, J., Quispe, J., et al. (2019). Unexpected receptor functional mimicry elucidates activation of coronavirus fusion. Cell 176, 1026-1039. doi: 10.1016/j.cell.2018.12.028

Wang, L., Shi, W., Chappell, J. D., Joyce, M. G., Zhang, Y., Kanekiyo, M., et al. (2018). Importance of neutralizing monoclonal antibodies targeting multiple antigenic sites on the middle east respiratory syndrome coronavirus spike glycoprotein to avoid neutralization escape. J. Virol. 92:10. doi: 10.1128/jvi. 02002-17

Ward, B. J., Gobeil, P., Séguin, A., Atkins, J., Boulay, I., Charbonneau, P.-Y., et al. (2020). Phase 1 trial of a candidate recombinant virus-like particle vaccine for COVID-19 disease produced in plants. medRxiv [preprint] doi: 10.1101/2020. 11.04.20226282 
Ward, B. J., Séguin, A., Couillard, J., Trépanier, S., and Landry, N. (2021). Phase III: Randomized observer-blind trial to evaluate lot-to-lot consistency of a new plant-derived quadrivalent virus like particle influenza vaccine in adults 18-49 years of age. Vaccine 39, 1528-1533. doi: 10.1016/j.vaccine.2021.01.004

World Health Organization (2021). Weekly epidemiological update - 6 March 2021 [Online]. Availableonline at: : https:/www.who.int/publications/m/item/ weekly-epidemiological-update-on-covid-19---6-april-2021 [accessed on Apr $11,2021]$

Xie, P., Ma, W., Tang, H., and Liu, D. (2020). Severe COVID-19: a review of recent progress with a look toward the future. Front. Publ. Health 8:189. doi: 10.3389/fpubh.2020.00189

Yang, C., Gao, X., and Gong, R. (2018). Engineering of Fc fragments with optimized physicochemical properties implying improvement of clinical potentials for Fc-based therapeutics. Front. Immunol. 8:1860. doi: 10.3389/fimmu.2017.01860

Yao, J., Weng, Y., Dickey, A., and Wang, K. Y. (2015). Plants as factories for human pharmaceuticals: applications and challenges. Int. J. Mol. Sci. 16, 28549-28565. doi: 10.3390/ijms161226122

Yuan, Y., Cao, D., Zhang, Y., Ma, J., Qi, J., Wang, Q., et al. (2017). CryoEM structures of MERS-CoV and SARS-CoV spike glycoproteins reveal the dynamic receptor binding domains. Nat. Commun. 8:15092. doi: 10.1038/ ncomms 15092

Yuki, K., Fujiogi, M., and Koutsogiannaki, S. (2020). COVID-19 pathophysiology: a review. Clin. Immunol. 215:108427. doi: 10.1016/j.clim.2020.108427

Yuki, Y., Mejima, M., Kurokawa, S., Hiroiwa, T., Takahashi, Y., Tokuhara, D., et al. (2013). Induction of toxin-specific neutralizing immunity by molecularly uniform rice-based oral cholera toxin B subunit vaccine without plantassociated sugar modification. Plant Biotechnol. J. 11, 799-808.

Zhang, N., Channappanavar, R., Ma, C., Wang, L., Tang, J., Garron, T., et al. (2016). Identification of an ideal adjuvant for receptor-binding domain-based subunit vaccines against Middle East respiratory syndrome coronavirus. Cell. Mol. Immunol. 13, 180-190. doi: 10.1038/cmi.2015.03
Zheng, N., Xia, R., Yang, C., Yin, B., Li, Y., Duan, C., et al. (2009). Boosted expression of the SARS-CoV nucleocapsid protein in tobacco and its immunogenicity in mice. Vaccine 27, 5001-5007. doi: 10.1016/j.vaccine.2009. 05.073

Zhou, P., Yang, X.-L., Wang, X.-G., Hu, B., Zhang, L., Zhang, W., et al. (2020). Discovery of a novel coronavirus associated with the recent pneumonia outbreak in humans and its potential bat origin. Nature 579, 270-273. doi: 10.1038/s41586-020-2012-7

Zhu, X., Liu, Q., Du, L., Lu, L., and Jiang, S. (2013). Receptor-binding domain as a target for developing SARS vaccines. J. Thorac. Dis. 5, 142-148. doi: 10.3978/j. issn.2072-1439.2013.06.06

Conflict of Interest: WP from Chulalongkorn University is a founder/shareholder of Baiya Phytopharm Co., Ltd. BS and KR are employed by Baiya Phytopharm Co., Ltd., Thailand. WW is employed by BioNet-Asia Co., Ltd., Thailand.

The remaining authors declare that the research was conducted in the absence of any commercial or financial relationships that could be construed as a potential conflict of interest.

Copyright () 2021 Siriwattananon, Manopwisedjaroen, Shanmugaraj, Rattanapisit, Phumiamorn, Sapsutthipas, Trisiriwanich, Prompetchara, Ketloy, Buranapraditkun, Wijagkanalan, Tharakhet, Kaewpang, Leetanasaksakul, Kemthong, Suttisan, Malaivijitnond, Ruxrungtham, Thitithanyanont and Phoolcharoen. This is an open-access article distributed under the terms of the Creative Commons Attribution License (CC BY). The use, distribution or reproduction in other forums is permitted, provided the original author(s) and the copyright owner(s) are credited and that the original publication in this journal is cited, in accordance with accepted academic practice. No use, distribution or reproduction is permitted which does not comply with these terms. 